\title{
Transcriptomic analysis of pathways regulated by toll-like receptor 4 in a murine model of chronic pulmonary inflammation and
} carcinogenesis

\author{
Alison K Bauer*1, Jennifer Fostel2 ${ }^{2}$, Laura M Degraff ${ }^{2}$, Elizabeth A Rondini' ${ }^{1}$, \\ Christopher Walker ${ }^{2}$, Sherry F Grissom ${ }^{3}$, Julie Foley ${ }^{4}$ and \\ Steven R Kleeberger ${ }^{2}$
}

\begin{abstract}
Address: ${ }^{1}$ Department of Pathobiology and Diagnostic Investigation, Michigan State University, East Lansing, MI, USA, ${ }^{2}$ Laboratory of Respiratory Biology, National Institute of Environmental Health Sciences, Research Triangle Park, NC, USA, ${ }^{3}$ Laboratory of Molecular Toxicology, National Institute of Environmental Health Sciences, Research Triangle Park, NC, USA and ${ }^{4}$ Laboratory of Cellular and Molecular Pathology, National Institute of Environmental Health Sciences, Research Triangle Park, NC, USA

Email: Alison K Bauer* - akbauer@msu.edu; Jennifer Fostel - fostel@niehs.nih.gov; Laura M Degraff - miller12@niehs.nih.gov; Elizabeth A Rondini - rondinie@msu.edu; Christopher Walker - christopher.walker2@duke.edu; Sherry F Grissom - sherryfgrissom@gmail.com; Julie Foley - foley1@niehs.nih.gov; Steven R Kleeberger - kleeber1@niehs.nih.gov

* Corresponding author
\end{abstract}

Published: 19 November 2009

Molecular Cancer 2009, 8:107 doi:10.1 186/1476-4598-8-107
Received: 14 September 2009

Accepted: 19 November 2009

This article is available from: http://www.molecular-cancer.com/content/8/I/I07

(c) 2009 Bauer et al; licensee BioMed Central Ltd.

This is an Open Access article distributed under the terms of the Creative Commons Attribution License (http://creativecommons.org/licenses/by/2.0), which permits unrestricted use, distribution, and reproduction in any medium, provided the original work is properly cited.

\begin{abstract}
Background: Therapeutic strategies exist for human pulmonary neoplasia, however due to the heterogeneity of the disease, most are not very effective. The innate immunity gene, toll-like receptor 4 (TLR4), protects against chronic pulmonary inflammation and tumorigenesis in mice, but the mechanism is unclear. This study was designed to identify TLR4-mediated gene expression pathways that may be used as prognostic indicators of susceptibility to lung tumorigenesis in mice and provide insight into the mechanism.

Methods: Whole lung mRNA was isolated from C.C3H-TIr4Lps-d (BALBLps-d; TIr4 mutant) and BALB/c (TIr4 normal) mice following butylated hydroxytoluene (BHT)-treatment (four weekly ip. injections; 150-200 mg/kg/each; "promotion"). mRNA from micro-dissected tumors (adenomas) and adjacent uninvolved tissue from both strains were also compared 27 wks after a single carcinogen injection (3-methylcholanthrene (MCA), $10 \mu \mathrm{g} / \mathrm{g}$; "control") or followed by BHT (6 weekly ip. injections; $125-200 \mathrm{mg} / \mathrm{kg} / \mathrm{each}$; "progression"). Bronchoalveolar lavage fluid was analyzed for inflammatory cell content and total protein determination, a marker of lung hyperpermeability; inflammation was also assessed using immunohistochemical staining for macrophages (F4/80) and lymphocytes (CD3) in mice bearing tumors (progression).
\end{abstract}

Results: During promotion, the majority of genes identified in the BALBLps-d compared to BALB/c mice $(P<0.05)$ were involved in epithelial growth factor receptor $(E G F R)$ signaling (e.g. epiregulin (Ereg)), secreted phosphoprotein I(SppI)), which can lead to cell growth and eventual tumor development. Inflammation was significantly higher in BALBLps-d compared to BALB/c mice during progression, similar to the observed response during tumor promotion in these strains. Increases 
in genes involved in signaling through the EGFR pathway (e.g. Ereg, Spp I) were also observed during progression in addition to continued inflammation, chemotactic, and immune response gene expression in the BALBLps-d versus BALB/c mice $(P<0.05)$, which appears to provide more favorable conditions for cell growth and tumor development. In support of these findings, the $\mathrm{BALB} / \mathrm{c}$ mice also had significantly reduced expression of many immune response and inflammatory genes in both the tumors and uninvolved tissue.

Conclusion: This transcriptomic study determined the protective effect of TLR4 in lung carcinogenesis inhibition of multiple pathways including EGFR (e.g. Ereg), inflammatory response genes (e.g. $C_{x c l 5}$ ), chemotaxis (e.g. $(\mathrm{crl})$ and other cell proliferation genes (e.g. Argl, Pthlh). Future studies will determine the utility of these pathways as indicators of immune system deficiencies and tumorigenesis.

\section{Introduction}

Adenocarcinoma (AC), a non-small cell lung carcinoma (NSCLC) [1], remains the leading type of lung cancer among smokers and nonsmokers. AC is often not detected until advanced stages of the disease thus making it the most clinically-intractable of lung cancers [1]. Therefore, it is critical to discover biomarkers of early stages of AC that would allow early detection and to find new sites at which chemopreventive agents could act to inhibit further neoplastic progression. Chronic inflammatory lung diseases, such as COPD and asthma, predispose to lung neoplasia [2-5]. Thus, inflammatory mediators and effector pathways might provide a source of early biomarkers and further insight into mechanisms of lung cancer.

Spontaneous or chemically-induced mouse lung neoplasms resemble those of human AC in anatomy, histogenesis, and molecular features [6], thereby facilitating mouse to human comparisons. Multiple exposures to butylated hydroxytoluene (BHT) elicit lung injury and inflammation during tumor promotion that are significantly correlated with tumor multiplicity in mice $[7,8]$. This 2-stage carcinogenesis model uses a low dose of a tobacco smokexs carcinogen, 3-methlycholanthrene (MCA), followed by multiple doses of BHT as the tumor promoter [9]. It is not BHT per se, but oxidative metabolites of BHT produced in high concentrations in mouse lung that are responsible for these pneumotoxicities and inflammatory activities [10]. Understanding the molecular events that occur early in the tumorigenic process (i.e. promotion including chronic inflammation and proliferation) may be critical to understanding the later events that occur during progression.

Tlr4 is an innate immunity gene involved in exacerbation of responses to several pulmonary agonists including endotoxin (lipopolysaccarride, LPS [11]) and ozone $\left(\mathrm{O}_{3}\right.$ [12]), and injury protection from pulmonary insults, including hyperoxia [13] and allergic inflammation [14]. Several epidemiological studies found significant decreases in lung cancer risk in individuals such as farm and textile workers that were exposed to endotoxin [1517]. Because TLR4 is the primary receptor that binds endotoxin [11], it is likely that TLR4 is involved in protection observed with endotoxin exposure. TLR4 also confers protection against human gastric and mouse cutaneous carcinomas $[18,19]$. The mechanism behind TLR4-mediated protection is unclear.

We previously demonstrated that TLR4 protects against BHT-induced chronic pulmonary inflammation and tumor promotion [20]. C.C3H-Tlr4Lps-d (BALB ${ }^{L p s-d}$ ) mice have a missense mutation in Tlr4 [21] that renders TLR4 dysfunctional. Bronchoalveolar lavage fluid (BALF) inflammatory markers were significantly elevated in BAL$\mathrm{B}^{L p s-d}$ mice compared to BALB/C (BALB; Tlr4 wild type) mice following BHT treatment [20]. Significantly increased tumor multiplicity $(60 \%)$ was also found in BALB $^{L p s-d}$ compared to BALB mice in response to MCA/ BHT induced tumor promotion. However, the downstream mechanism regulating this protective response remains unknown.

In the present investigation, we hypothesized that gene transcripts that are highly correlated to TLR4 associate with differential susceptibility to an early stage (BHTtreatment) and a later stage (progression) of lung tumorigenesis. To test this hypothesis we used two methods to analyze transcriptome responses in lung tissue from BALB and BALB ${ }^{L p s-d}$ mice during promotion, and in tumors and uninvolved lung tissue in advanced stages of tumorigenesis. The first statistical method (supervised) assigned a significance value to transcript changes. The second method (unsupervised, pattern analysis) used $k$-means clustering to identify additional patterns which may have remained hidden. These methods identified changes in transcripts known to be downstream of TLR4 and others not previously linked to this gene. We suggest that these pathways and interactions amongst the genes identified during tumor promotion influence the TLR4-mediated response observed during progression of tumorigenesis. 


\section{Methods \\ Animals}

Male 5-7 wk. old BALB/c (BALB; Tlr4 wild type) and C.C3Tlr $4^{L p s-d} / \mathrm{J}$ (BALB ${ }^{L p s-d}$; Tlr4 dominant negative) mice were purchased from Jackson Laboratories (Bar Harbor, ME). Mice acclimated for $1 \mathrm{wk}$ prior to treatment. All animal use was conducted in facilities accredited by the Association for the Assessment and Accreditation of Laboratory Animal Care and approved by the NIEHS Animal Care and Use Committee and the MSU Institutional Animal Care and Use Committee. Mice were housed in shoebox cages in a humidity and temperature-controlled room and provided water and pelleted open-formula rodent diet NIH-07 (Zeigler Brothers, Gardners, PA.) ad libitum.

\section{Experimental design}

The two protocols used for these studies (see Additional file 1, Figure S1) were based on previous studies demonstrating a correlation between chronic inflammation and tumor promotion [7]. To induce inflammation (Protocol 1: promotion; Additional file 1, Figure S1: A), mice were injected intraperitoneally (ip.) with BHT (Sigma, St. Louis, MO) weekly for 4 weeks $(150 \mathrm{mg} / \mathrm{kg}$ for the first dose followed by $200 \mathrm{mg} / \mathrm{kg}$ for the next 3 doses). Mice were then sacrificed 1 or 3 days following the last BHT dose. For BHT-induced tumor studies (Protocol 2: progression stage; Additional file 1: Figure S1: B), $10 \mu \mathrm{g} \mathrm{MCA} /$ gm (Sigma) body wt. was injected ip., followed by $150 \mathrm{mg}$ $\mathrm{BHT} / \mathrm{kg}$ or corn oil vehicle control one week later. Five additional weekly $200 \mathrm{mg} / \mathrm{kg}$ BHT doses or vehicle control doses were administered to maximize tumor promotion [22]. Mice were sacrificed 27 wks after MCA injection. Because fewer than 0.5 tumors/mouse result from MCA alone, the tumors that develop after MCA/BHT treatment are primarily those promoted by MCA.

The left lung of each mouse was clamped off at the mainstem bronchus and the right lung was lavaged for inflammatory infiltrate analysis $[12,20]$. Briefly, four aliquots of HBSS (Sigma) were inserted sequentially into the lung based on body weight $(17.5 \mathrm{ml} / \mathrm{kg})$. The first lavage was used for protein analysis (BioRad protein assay, BioRad, Hercules, CA) as a measure of lung hyperpermeability. Total pooled cells from the four lavages were then counted, followed by cytocentrifugation (Shandon Southern Products, Pittsburgh, PA). The slides were then stained with a modified Wright's stain (Hema 3 Stain Set, Fisher Scientific, Pittsburgh, PA) to differentiate inflammatory cells by morphology, including PMNs, alveolar macrophages, lymphocytes, and epithelial cells. The left lung was snap frozen in liquid nitrogen. For MCA/BHT treated mice (Protocol 2), the lavaged right lung was inflationfixed with $10 \%$ formalin, processed, and embedded. Tumors (adenomas) were carefully micro-dissected away from the adjacent tissue on left lung lobe using a Leica S6D stereo microscope (Leica Microsystems, Inc., Bannockburn, IL) and then snap frozen, similar to other studies [23-25]. Remaining whole lung tissue was used as the uninvolved tissue. In addition, whole lung tissue was also used for the MCA/oil treatment group. Due to the manner in which the tumors were micro-dissected away from the normal adjacent uninvolved tissue, there is a possibility that the uninvolved tissue may contain some remaining smaller lesions as well as tumor cells from the periphery.

\section{Immunohistochemistry for CD3 and F4/80}

$5 \mu \mathrm{m}$ thick sections were stained using antibodies for CD3 (ab5690; Abcam, Cambridge, MA) as a pan-T-lymphocyte marker and F4/80 (MF48000; Caltag, Burlingame, CA) as a macrophage marker, following standard protocols at: http://www.niehs.nih.gov/research/atniehs/labs/lep/ path-support/immuno/.

\section{Total lung RNA isolation and cDNA synthesis for mRNA analyses}

Total RNA was isolated from the left lung lobe using RNeasy Mini Kits (Qiagen, Valencia, CA) following kit specifications, including DNase 1 treatment. CDNA was synthesized as described previously [26]. For Protocol 1, RNA was isolated from each of three replicate mice for each experimental group (experimental groups = oil control, 1-day, and 3-days after BHT, three replicated per group). For Protocol 2, tumors from 2 to 3 mice were pooled to obtain sufficient material; uninvolved tissue from the same mice was also pooled for control. There were two replicates for each experimental group (MCA/ oil, MCA/BHT tumor tissue and MCA/BHT uninvolved tissue) except for the BALB tumor group where the incidence of tumors was low.

\section{Affymetrix Mouse 430A_MOE array analysis}

Total RNA was used only after it passed quality testing performed using a 2100 Bioanalyzer (Agilent Technologies, Inc., Santa Clara, CA). Gene expression analysis was conducted using Affymetrix MOE430A or MOE430Av2 GeneChip $^{\circledast}$ arrays (Affymetrix, Santa Clara, CA) as recommended by the manufacturer. Total RNA $(1 \mu \mathrm{g})$ was amplified using the Affymetrix One-Cycle cDNA Synthesis protocol. For each array, $15 \mu \mathrm{g}$ of amplified biotin-cRNAs was fragmented and hybridized to the array for 16 hours at $45^{\circ} \mathrm{C}$ in a rotating hybridization oven using the Affymetrix Eukaryotic Target Hybridization Controls and protocol. Slides were stained with steptavidin/phycoerythrin using a double-antibody staining procedure and washed utilizing the Mini_euk2v3 Protocol of the Affymetrix Fluidics Station FS450 for antibody amplification. Arrays were scanned with an Affymetrix Scanner 3000 and data obtained using the GeneChip ${ }^{\circledast}$ Operating Software. 
The CEL files for each array type were normalized and genes with altered expression level were selected using kmeans clustering and ANOVA $(\mathrm{p}<0.05)$. The raw data discussed in this publication have been deposited into NCBI Gene Expression Omnibus (GEO, http:// www.ncbi.nlm.nih.gov/geo/, Series GSE8504) and NIEHS Chemical Effects in Biological Systems (CEBS, http:// cebs.niehs.nih.gov/, accession 005-00003-0030-000-1). Starting and ending gene lists are found in Additional file 2 , Table S1. The details of the process to identify genes with altered transcript levels using the supervised and unsupervised methods are found in Additional file 3.

\section{Quantitative real time PCR (qRTPCR)}

qRTPCR was performed using Sybr green assays on an Applied Biosystems 7900 Prism Sequence Detection System as follows: $12.5 \mu$ l Power Sybr Green PCR master mix (Applied Biosystems, Foster City, CA), $200 \mathrm{nM}$ forward and reverse primers, $5.5 \mu \mathrm{l}$ nuclease-free $\mathrm{dH}_{2} \mathrm{O}$, and $2 \mu \mathrm{l}$ of cDNA per $25 \mu \mathrm{l}$ reaction. The reverse and forward primers can be found in Additional file 4, Table S2. PCR reaction conditions and data analysis were performed according to the manufacturer's protocol (User bulletin no.2, Applied Biosystems Prism 7700 Sequence Detection System). $18 \mathrm{~S}$ was used to normalize all genes of interest since it did not vary across genotypes or treatments. Some transcript changes identified by microarray analysis were confirmed using qRTPCR in the same samples (Protocol 1 ) and in the same samples plus samples from a parallel study (Protocol 2).

\section{Statistics for BALF analysis and qRTPCR}

Data are expressed as the group mean \pm SEM. Two-way ANOVA was used to evaluate the effects of strain (BALB vs. BALB $^{\text {Lps-d }}$ ) and treatment (MCA/oil and MCA/BHT) on BAL phenotypes. A 3-way ANOVA was performed for treatment, time $(0,1$, or 3 days), and strain effects on mRNA expression data under Protocol 1 (promotion). A 2-way ANOVA was performed for the treatment (MCA/ oil, MCA/BHT tumor tissue, and MCA/BHT uninvolved tissue) and strain effects on mRNA expression data under Protocol 2 (progression). Student-Newman-Keuls test was used for a posteriori comparisons of means. All analyses were performed using a commercial statistical analysis package (SigmaStat; Jandel Scientific Software, San Rafael, CA). Statistical significance was accepted at $P<0.05$.

\section{Results}

BHT-induced transcriptome changes between BALB vs. BALB ${ }^{L p s-d}$ mice during tumor promotion (Protocol I, "Promotion")

Three different gene expression profiles were identified (genes for each are in Additional file 2, Table S1, Tab A). Figure 1 and Additional file 5, Figure S2 illustrate one of
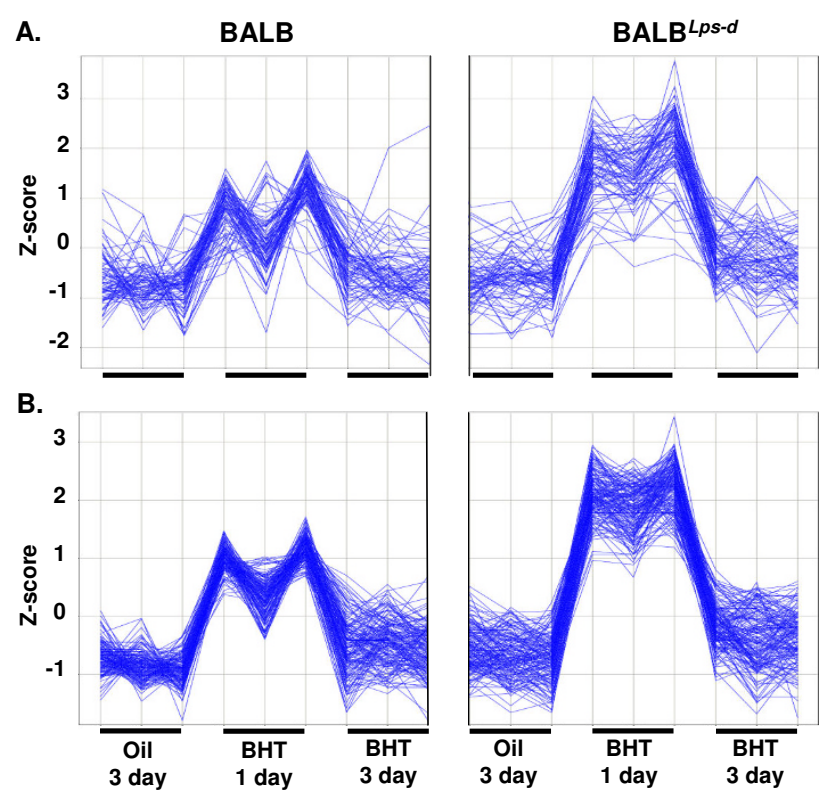

Figure I

Gene expression that increased in the BALBLps-d mice compared to BALB mice following chronic BHT. Two methods of analysis, supervised and unsupervised, were used to determine the genes increased at I day following BHT. A. Cluster 3 identified using statistical (GeneSpring) analysis in chronic BHT-treated BALB and BALBLps-d mice over a time course (oil and I and 3 day following chronic BHT). Each vertical line represents one sample for each strain for an $n=3$ (oil, BHT I day, BHT 3 day), indicated by the small horizontal black line above each treatment on the $x$-axis. B. Profile analysis (Spotfire) similar to that of cluster 3. Each vertical line represents one sample for each strain for an $n=3$ (oil, BHT I day, BHT 3 day). Z-score ( $y$-axis) is the intensity in terms of standard deviations (SD) from the mean. The z-score was calculated by subtracting the mean and dividing by the SD for each probeset. See Additional file 5, Figure S2 for supervised and unsupervised analyses depicted as a heat map.

the profiles found by supervised (Fig 1A) and unsupervised (Fig 1B) methods. The profiles are biologically similar, i.e. expression increased by one standard deviation (BALB) or more (BALB ${ }^{L p s-d}$ ) in mice sampled one day following the last BHT injection compared to mice three days after BHT, or mice receiving oil vehicle control. We termed this profile "BHT_1day_up". Some genes with this profile were identified by both methods, and others found by only one method. We also found two BHT_1day_down profiles by supervised and unsupervised methods (see Additional file 2, Table S1, Tab A).

Transcripts with the BHT_1day_up profile have Gene Ontology (GO) functions involving cell cycle and growth, transcription, cell shape and morphogenesis, protein syn- 
Table I: Representative gene expression changes increased in BALBLsp-d compared to BALB mice.

\begin{tabular}{|c|c|c|c|}
\hline Gene Symbol & Gene Name & Affymetrix Probe ID & Major GO Category(ies) \\
\hline \multicolumn{4}{|l|}{ Angiogenesis } \\
\hline Hbegft & heparin-binding EGF-like growth factor & 1418349_at & angiogenesis; blastocyst growth \\
\hline $\mathrm{Mmp} / 9 \dagger$ & matrix metallopeptidase 19 & |421977_at & angiogenesis; peptidoglycan metabolic process \\
\hline Timplt & tissue inhibitor of metallo-proteinase I & 1460227_at & erythrocyte maturation \\
\hline \multicolumn{4}{|c|}{ Cell cycle and cell growth } \\
\hline Cdknla & cyclin-dependent kinase inhibitor IA (P2I) & 1424638_at & $\begin{array}{l}\text { regulation of progression through cell cycle; response to } \\
\text { DNA damage stimulus }\end{array}$ \\
\hline Ereg & epiregulin & |41943|_at & regulation of progression through cell cycle; angiogenesis \\
\hline Mina & myc induced nuclear antigen & 1451042_a_at & regulation of cell proliferation \\
\hline Myct & myelocytomatosis oncogene & 1424942_a_at & $\begin{array}{l}\text { regulation of progression through cell cycle; release of } \\
\text { cytochrome c from mitochondria }\end{array}$ \\
\hline Socs3 & suppressor of cytokine signaling 3 & 1455899_x_at & $\begin{array}{l}\text { regulation of cell growth; regulation of protein amino } \\
\text { acid phosphorylation }\end{array}$ \\
\hline \multicolumn{4}{|c|}{ Cell shape and morphogenesis } \\
\hline Krt 19 & keratin 19 & 1417156_at & cytoskeleton organization and biogenesis \\
\hline Tnct & tenascin C & 1416342_at & cell adhesion \\
\hline Tubalc & tubulin, alpha IC & 1416128 at & microtubule-based process and movement \\
\hline \multicolumn{4}{|c|}{ Inflammatory and immune response } \\
\hline $116+$ & interleukin 6 & |450297_at & neutrophil apoptosis \\
\hline Lift & leukemia inhibitory factor & 1421207_at & $\begin{array}{l}\text { immune response; tyrosine phosphorylation of stat } 3 \\
\text { protein }\end{array}$ \\
\hline Spplt & secreted phosphoprotein I & | 449254_at & ossification; anti-apoptosis \\
\hline \multicolumn{4}{|c|}{ Protein synthesis and turnover } \\
\hline Eifla & eukaryotic translation initiation factor IA & 1419736_a_at & translation and initiation \\
\hline Hras $I^{\dagger}$ & Harvey rat sarcoma virus oncogene I & 1422407_s_at & translation; endocytosis \\
\hline Nolal & nucleolar protein family $\mathrm{A}$, member I & 1418305_s_at & rRNA processing; ribosome biogenesis and assembly \\
\hline Nola2 & nucleolar protein family A, member 2 & 1416605_at & rRNA processing; translation \\
\hline Nol5A & nucleolar protein 5 & 1450986_at & ribosome biogenesis and assembly \\
\hline $\mathrm{Nmd3}$ & NMD3 homolog & 1437238_x_at & ribosomal large subunit export from nucleus \\
\hline Rps6ka3 & ribosomal protein S6 kinase polypeptide 3 & 1427299_at & $\begin{array}{l}\text { protein amino acid phosphorylation; ribosome biogenesis } \\
\text { and assembly }\end{array}$ \\
\hline \multicolumn{4}{|c|}{ Protein targeting } \\
\hline Afp ${ }^{\dagger}$ & alpha fetoprotein & 1416646_at & ovulation; transport \\
\hline$B c 13^{\dagger}$ & B-cell leukemia/lymphoma 3 & 1418133_at & $\begin{array}{l}\text { protein import into nucleus, translocation; follicular } \\
\text { dendritic cell differentiation }\end{array}$ \\
\hline Bnip I & $\begin{array}{l}\text { BCL2/adenovirus EIB interacting protein I, } \\
\text { NIPI }\end{array}$ & 1427908_at & ER to Golgi vesicle-mediated transport; apoptosis \\
\hline Nup62 & Nucleoporin 62 & |4389|7_x_at & protein targeting; transport \\
\hline \multicolumn{4}{|c|}{ Transcription, processing, and chromatin structure } \\
\hline Bhlhb8 & $\begin{array}{l}\text { basic helix-loop-helix domain containing, } \\
\text { class B, } 8\end{array}$ & 1449233_at & regulation of transcription, DNA-dependent \\
\hline Ddx39 & $\begin{array}{l}\text { DEAD (Asp-Glu-Ala-Asp) box polypeptide } \\
39\end{array}$ & 1423643_at & mRNA processing; RNA splicing \\
\hline Hmgalt & high mobility group AT-hook I & |416184_s_at & DNA packaging; transcription \\
\hline Lmna & lamin A & 1425472_a_at & nuclear membrane organization and biogenesis \\
\hline Pparg ${ }^{\dagger}$ & $\begin{array}{l}\text { peroxisome proliferator activated receptor } \\
\text { gamma }\end{array}$ & 14207|5_a_at & $\begin{array}{l}\text { negative regulation of transcription from RNA } \\
\text { polymerase II promoter }\end{array}$ \\
\hline
\end{tabular}

These genes were identified in profile "BHT-I day_up" (A) and profile "BHT-I day_down" (B) below the p value set for the DAVID analysis (P < $0.0003)^{*}$; see Additional file 2, Table SI for the complete profile gene lists.

*These genes were identified after bioinformatic analysis filtering first on biological patterns using both Genespring and Spotfire Software followed by filtering on GO biological categories using the DAVID Bioinformatics Database. TThese genes were upregulated $\geq 2$-fold in BALBLsp-d vs. BALB I day following protocol I (chronic BHT) $(P<0.05)$. SSignificant interaction effects between strain (BALB vs BALBLpsd mice) and treatment (oil, I or 3 days following 4BHT) $(\mathrm{p}<0.05)$. Bolded genes are those genes in common with the gene list identified for Protocol 2 (see Table 2). 
Table 2: Representative gene expression changes decreased in BALBLsp-d compared to BALB mice.

\begin{tabular}{|c|c|c|c|}
\hline \multicolumn{4}{|l|}{ B. } \\
\hline Gene Symbol* & Gene Name & Affymetrix Probe ID & Major GO Category(ies) \\
\hline \multicolumn{4}{|c|}{ Cell cycle and cell growth } \\
\hline Csflr & colony stimulating factor I receptor & 1419872_at & $\begin{array}{l}\text { regulation of progression through cell cycle; } \\
\text { protein amino acid phosphorylation }\end{array}$ \\
\hline $\mathrm{Fg} 7^{\dagger}$ & fibroblast growth factor 7 & 1422243_at & $\begin{array}{l}\text { regulation of progression through cell cycle;; signal } \\
\text { transduction }\end{array}$ \\
\hline Gas6 & growth arrest specific 6 & 1417399_at & regulation of cell growth \\
\hline Htral & htrA serine peptidase I & 1416749_at & regulation of cell growth; proteolysis \\
\hline $\operatorname{ltm} 2 b$ & integral membrane protein $2 B$ & 1418000_a_at & apoptosis \\
\hline \multicolumn{4}{|c|}{ Cell shape and morphogenesis } \\
\hline $\operatorname{ltg} a 8^{\dagger}$ & integrin alpha 8 & |427489_at & cell adhesion \\
\hline Nox4t & NADPH oxidase 4 & 1419161_a_at & cell morphogenesis; electron transport \\
\hline Pik3rl† & $\begin{array}{l}\text { phosphatidylinositol 3-kinase, regulatory subunit, } \\
\text { polypeptide I (p85 alpha) }\end{array}$ & |425515_at & $\begin{array}{l}\text { negative regulation of cell-matrix adhesion; protein } \\
\text { amino acid phosphorylation }\end{array}$ \\
\hline Postn & periostin, osteoblast specific factor & 1423606_at & cell adhesion \\
\hline \multicolumn{4}{|c|}{ Protein targeting } \\
\hline Arl6ip I & $\begin{array}{l}\text { ADP-ribosylation factor-like } 6 \text { interacting } \\
\text { protein I }\end{array}$ & |45||3|_at & cotranslational protein targeting to membrane \\
\hline Tmod I & tropomodulin I & 1422754_at & myofibril assembly; muscle thick filament assembly \\
\hline \multicolumn{4}{|c|}{ Transcription, processing, and chromatin structure } \\
\hline$H p / b p 3$ & heterochromatin protein I, binding protein 3 & |4|575|_at & nucleosome assembly \\
\hline KIfI5 & Kruppel-like factor 15 & |448|8|_at & regulation of transcription, DNA-dependent \\
\hline Rorat & RAR-related orphan receptor alpha & |420583_a_at & regulation of transcription, DNA-dependent \\
\hline Slu 7 & SLU7 splicing factor homolog & 1420030_at & alternative nuclear mRNA splicing, via spliceosome \\
\hline
\end{tabular}

* These genes were identified after bioinformatic analysis filtering first on biological patterns using both Genespring and Spotfire Software followed by filtering on GO biological categories using the DAVID Bioinformatics Database. These genes were down-regulated $\geq 2$-fold in BALBLsp-d vs. BALB I day following protocol I (chronic BHT) $(\mathrm{P}<0.05)$

thesis, protein targeting, and inflammatory and immune response (Table 1). Transcripts with the BHT_1day_down profile have functions related to cell cycle and growth, cell shape, protein targeting, and transcription (Table 2). The BHT_1day_up profile also includes genes with inflammation and immune response functions, as would be expected based on the BALF inflammation cell analysis from the same animals (data not shown).

An additional expression profile identified by unsupervised analysis only consists of genes with decreased transcript levels 1 day following BHT treatment that recover to control levels in BALB mice 3 days following BHT, but are still depressed in BALB ${ }^{L p s-d}$ (see Additional file 2, Table S1, Tab A, column N).

We confirmed the change in transcript level seen in the microarray analysis using qRTPCR. We used RNA from the same samples used for microarray analysis and, in the case of Protocol 2, samples from a repeat study with the same design. qRTPCR analyses confirmed the changes in expression seen by microarray analysis in genes listed in Table 1 (epiregulin (Ereg), tenacin C (Tnc), secreted phosphoprotein $1(S p p 1)$, and peroxisome proliferator acti- vated receptor gamma (Pparg)), as well as other genes with profile "BHT-1day_up" (chemokine (C-C motif) ligand 17 (Ccl17), fos-like antigen 1 (Fosl1)) that did not fall below the $\mathrm{p}$ value for DAVID, but were significantly different between strains (Figure 2).

\section{Pulmonary inflammation differences between the BALB vs. BALBLps-d mice during the progression stage of tumorigenesis (Protocol 2, "Progression")}

BALB ${ }^{L p s d}$ mice develop significantly more tumors after MCA/BHT than wild type BALB mice or than BALB ${ }^{\text {Lpsd }}$ mice after MCA/oil treatment [20]. We found mean BALF total protein content and numbers of macrophages, lymphocytes, and epithelial cells were significantly increased during progression $(\mathrm{p}<0.05)$ in the tumor bearing MCA/ BHT BALB ${ }^{L p s-d}$ mice compared to the BALB ${ }^{\text {Lps- } d}$ MCA/oil controls (Figure 3A). No increases in inflammatory cell infiltrates were found in the wildtype BALB mice after either MCA/oil or MCA/BHT.

Histological staining of the same lungs with anti-F4/80 or anti-CD3 markers for macrophages or T-lymphocytes, respectively, confirmed the BALF results (Figure 3B). AntiF4/80 and anti-CD3 were found primarily adjacent to but 

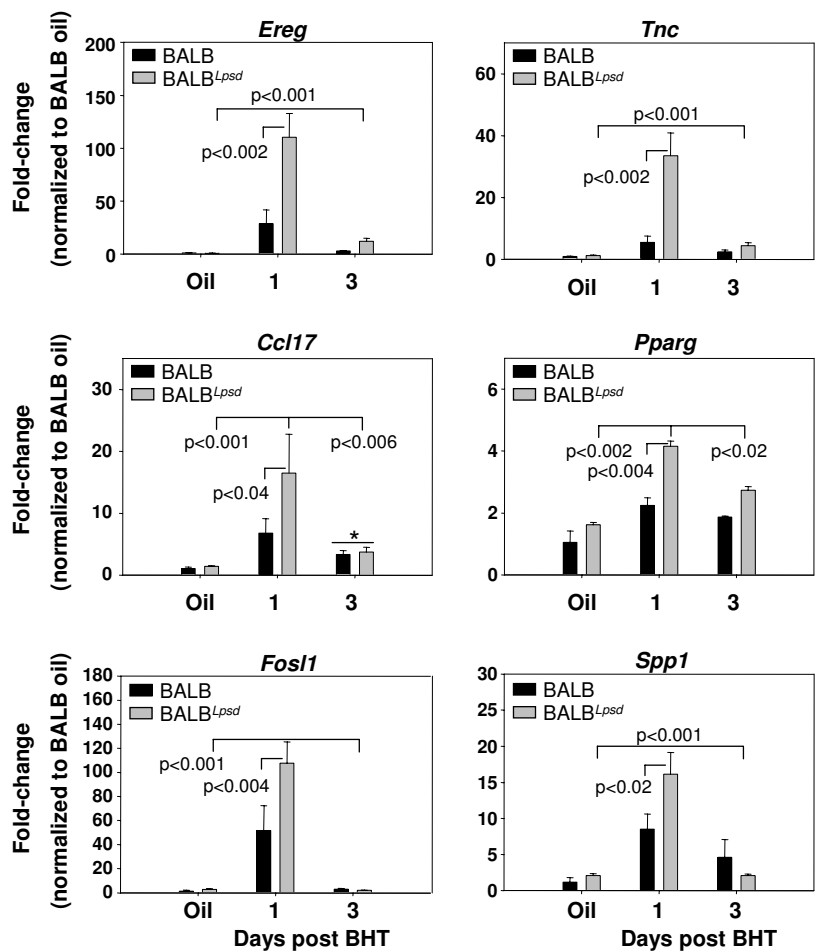

Figure 2

Confirmation of select genes identified using protocol I (chronic BHT) in BALB and BALBLps-d mice.

These genes were selected using the supervised method of microarray analysis in both strains I and 3 days following BHT. Mean and SEM are presented; $n=3$ mice/experimental group for all. $P$ values are indicated on the graphs for each gene; the lines indicate comparisons between BHT treatment and corn oil control vehicle or between BALBLps-d compared to BALB mice. * $\mathrm{P}<0.05$ for 3 day following BHT treatment versus corn oil vehicle for $\mathrm{Ccll} 7$, and no difference was found between BALBLps-d and BALB mice.

not in the tumor parenchyma in $\mathrm{BALB}^{L p s-d}$ mice; this peritumoral staining was not seen in BALB mouse tumors.

Adenoma tumor size and morphology were not significantly different between the strains (data not shown), suggesting the difference in inflammation is not due to different stages of tumorigenesis or different tumor morphologies. Few F4/80- or CD3-positive-staining macrophages or lymphocytes were found in the MCA/oil lung sections from either strain (data not shown).

Transcriptome changes between the BALB vs. BALB ${ }^{L p s-d}$ mice during the progression stage of tumorigenesis (Protocol 2, "Progression")

We next assessed gene expression differences in control (MCA/oil) tissue, MCA/BHT dissected tumor tissue, and MCA/BHT uninvolved tissue, i.e. tissue remaining after
A.
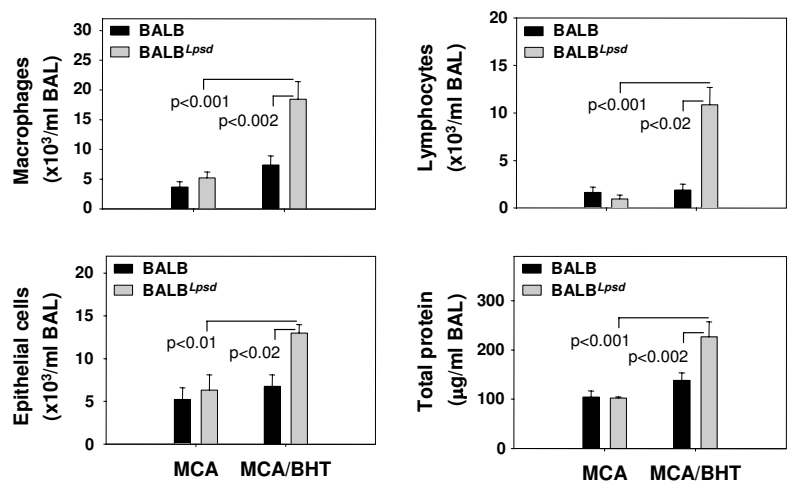

B.

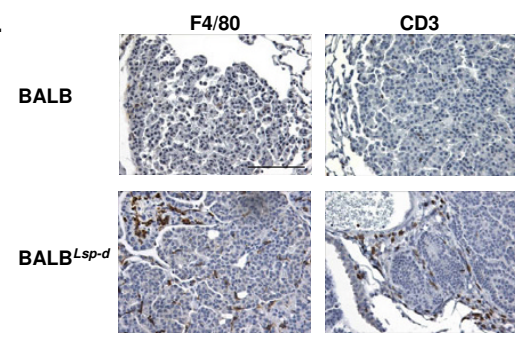

Figure 3

Comparison of inflammatory infiltrates in tumorbearing BALB and BALB ${ }^{\text {Lps-d }}$ mice 27 wks post carcinogen. A. Total BALF macrophages, lymphocytes, epithelial cells and protein recovered from BALB and BALBLps-d mice after MCA or MCA/BHT treatment. Significant increases in inflammation in tumor-bearing mice were found in BALBLps-d compared to BALB mice. Mean and SEM are presented; $n=6$ mice/experimental group. $P$ values are indicated on the graphs for each phenotype (macrophages, lymphocytes, epithelial cells, and total protein); comparisons are between MCA/BHT treatment groups and MCA/oil vehicle or between BALB and BALBLps-d mice. B. Immunohistological staining in BALB and BALBLps-d mice after 27 wks after MCA/ $\mathrm{BHT}$ treatment for macrophages and T-lymphocytes using F4/80 and CD3 markers, respectively. Bar indicates $100 \mu \mathrm{m}$. Slides were counterstained with hematoxylin.

tumor dissection in the same mice. We identified three biological profiles: up in tumor tissue relative to MCA alone or uninvolved tissue in the BALB mice and compared to the tumor tissue in BALB ${ }^{L p s-d}$ mice ("up in WT tumor"); up in tumor tissue compared to MCA alone or uninvolved tissue, and more so in BALB ${ }^{L p s-d}$ than BALB ("up in KO tumor"; Figure 4 and Additional file 6, Figure S3); and down in tumor compared to MCA alone or uninvolved tissue, and more so in BALB than in BALB ${ }^{L p s-d}$ ("down in WT tumor"). As before, we found that supervised and unsupervised analysis methods identified overlapping response profiles, which we combined into the three profiles described (i.e. 6 gene expression patterns, 3 per analysis). All genes in these profiles are listed in Additional file 2, Table S1, Tab A. We then analyzed GO path- 
Table 3: Representative gene expression changes increased in BALBLps-d tumors.

\begin{tabular}{|c|c|c|c|}
\hline Gene Symbol & Gene Name & Affymetrix Probe ID & Major GO Category(ies) \\
\hline \multicolumn{4}{|l|}{ Angiogenesis } \\
\hline Anpep & alanyl aminopeptidase & |42|424_a_at & angiogenesis; proteolysis \\
\hline Collsalt & procollagen, type XVIII, alpha I & 1418237_s_at & angiogenesis \\
\hline Nus I & $\begin{array}{l}\text { nuclear undecaprenyl pyrophosphate synthase I } \\
\text { homolog }\end{array}$ & 1419915_at & angiogenesis; multicellular organismal development \\
\hline \multicolumn{4}{|c|}{ Apoptosis and cell death } \\
\hline$B c \mid 2 / 14$ & bcl2-like I4 & |4248|4_a_at & apoptosis \\
\hline Cidebt & $\begin{array}{l}\text { cell death-inducing DNA fragmentation factor, } \\
\text { alpha subunit-like effector B }\end{array}$ & 1418976_s_at & apoptosis; induction of apoptosis \\
\hline Pglyrp I & peptidoglycan recognition protein I & |449|84_at & apoptosis; immune response \\
\hline \multicolumn{4}{|c|}{ Cell cycle and cell growth } \\
\hline Aspm & asp-like, microcephaly associated & |4228|4_at & cell cycle; mitosis \\
\hline Ereg ${ }^{\dagger}$ & Epiregulin & |4|943|_at & $\begin{array}{l}\text { regulation of progression through cell cycle; } \\
\text { angiogenesis }\end{array}$ \\
\hline Cenpf & centromere protein $\mathrm{F}$ & |427|6|_at & $\mathrm{G} 2$ and $M$ phase of mitotic cell cycle \\
\hline Mycn & $\begin{array}{l}\text { v-myc myelocytomatosis viral related oncogene, } \\
\text { neuroblastoma derived }\end{array}$ & & $\begin{array}{l}\text { regulation of progression through cell cycle; } \\
\text { regulation of transcription, DNA-dependent }\end{array}$ \\
\hline \multicolumn{4}{|c|}{ Immune response } \\
\hline Clcfl & cardiotrophin-like cytokine factor I & 1437270_a_at & $\begin{array}{l}\text { cell surface receptor linked signal transduction; JAK- } \\
\text { STAT cascade }\end{array}$ \\
\hline Flt3l & FMS-like tyrosine kinase 3 ligand & |422||5_a_at & lymphocyte differentiation \\
\hline $\mathrm{H} 2-\mathrm{oa}$ & histocompatibility $2, \mathrm{O}$ region alpha locus & 1419297_at & $\begin{array}{l}\text { immune response; antigen processing and } \\
\text { presentation }\end{array}$ \\
\hline Klrb Ib & $\begin{array}{l}\text { killer cell lectin-like receptor subfamily B } \\
\text { member IB }\end{array}$ & |42042|_s_at & $\begin{array}{l}\text { negative regulation of natural killer cell mediated } \\
\text { cytotoxicity }\end{array}$ \\
\hline Raet la & retinoic acid early transcript I, alpha & 1420603_s_at & $\begin{array}{l}\text { positive regulation of immune response to tumor } \\
\text { cell }\end{array}$ \\
\hline \multicolumn{4}{|c|}{ Inflammatory response and chemotaxis } \\
\hline $\mathrm{Ccr}$ & chemokine ( $\mathrm{C}-\mathrm{C}$ motif) receptor I & 1419610_at & inflammatory response; signal transduction \\
\hline Cxcl4t; Pf4 & $\begin{array}{l}\text { platelet factor } 4 \text {; chemokine (C-X-C motif) } \\
\text { ligand } 4\end{array}$ & 1448995_at & chemotaxis; immune response \\
\hline $\begin{array}{l}\text { Cxc15, Ena- } \\
\quad 78\end{array}$ & chemokine (C-X-C motif) ligand 5 & |4|9728_at & chemotaxis; inflammatory response \\
\hline Cxcl9†, Mig & chemokine (C-X-C motif) ligand 9 & |4|8652_at & inflammatory response; immune response \\
\hline Cxcll It, Itac & chemokine ( $\mathrm{C}-\mathrm{X}-\mathrm{C}$ motif) ligand II & |419697_at & chemotaxis; inflammatory response \\
\hline Kngl & kininogen I & |416676_at & inflammatory response; blood coagulation \\
\hline Spplt & secreted phosphoprotein I & |449254_at & ossification; anti-apoptosis \\
\hline \multicolumn{4}{|c|}{ Protein synthesis and turnover } \\
\hline Cdkn2a† & cyclin-dependent kinase inhibitor $2 \mathrm{~A}$ & |450|40_a_at & $\begin{array}{l}\text { regulation of cyclin-dependent protein kinase } \\
\text { activity; cell cycle }\end{array}$ \\
\hline$C f i \ddagger$ & Complement component factor i & |4|8724_at & proteolysis; immune response \\
\hline Gzme & granzyme E & |42|227_at & proteolysis; cytolysis \\
\hline FIO & coagulation factor $X$ & 1449305_at & proteolysis \\
\hline
\end{tabular}

These genes were identified in the "Up-in-KO_tumor" profile (A) and "Down in WT tumor" profile (B) that are below the $p$ value set for the DAVID analysis $(p<0.000 I)$; see Additional file 2 , Table SI for the complete profile gene lists.

*Representative increased genes from the "Up-in-KO_tumor" profile that were higher in the BALBLpsd tumors compared to BALB mice. These genes were identified after bioinformatic analysis filtering first on biological patterns using both Genespring and Spotfire Software followed by filtering on GO biological categories using the DAVID Bioinformatics Database. TGenes upregulated $\geq 1.5-2$-fold in BALBLspd tumors vs. BALB tumors based on GeneSpring. $¥$ Genes with significant interaction effects comparing strain (BALB vs BALBLspd) and treatment (MCA, MCA/BHT tumors, MCA/BHT uninvolved tissue) $(P<0.05)$. Bolded genes are those genes in common with the gene list identified for the 4BHT study (see Table I). 
ways for the genes in these three profiles using DAVID (Additional file 2: Table S1, Tab B, genes within selection criteria; Tab D are the GO categories for late genes). Transcripts with "up in KO tumor" profiles are associated with immune response, inflammatory response and chemotaxis, apoptosis and cell death, protein synthesis and turnover, and cell cycle and cell growth (Table 3 ). Transcripts with "down in WT tumor" profiles are primarily associ- ated with immune response and inflammation (Table 4). Transcripts with "up in WT tumor" profiles are associated with angiogenesis, protein synthesis, and immune responses.

qRTPCR was done to confirm the expression identified by microarray analysis (Figure 5) on select genes from Table 3 (collagen, type XVIII, alpha 1 (Col18a1), complement

Table 4: Representative gene expression changes decreased in BALB tumors.

\begin{tabular}{|c|c|c|c|}
\hline Gene Symbol & Gene Name & Affymetrix Probe ID & Major GO Category(ies) \\
\hline \multicolumn{4}{|l|}{ Angiogenesis } \\
\hline FI3al & coagulation factor $\mathrm{XIII}, \mathrm{AI}$ subunit & 1448929_at & $\begin{array}{l}\text { tRNA aminoacylation for protein translation; blood } \\
\text { coagulation }\end{array}$ \\
\hline$K d r \dagger$ & kinase insert domain protein receptor & 1449379_at & angiogenesis; ovarian follicle development \\
\hline Tbx $1+$ & T-box I & 1425779_a_at & angiogenesis; blood vessel development \\
\hline \multicolumn{4}{|c|}{ Apoptosis and cell death } \\
\hline Rassf5 & ras association (RalGDS/AF-6) domain family 5 & 1422637_at & apoptosis; cell cycle \\
\hline Unc5c & unc-5 homolog $C$ & 1449522_at & apoptosis; signal transduction \\
\hline \multicolumn{4}{|c|}{ Immune response } \\
\hline $\mathrm{Cd} 3 \mathrm{~d}^{\dagger}$ & CD3 antigen, delta polypeptide & 1422828_at & $\begin{array}{l}\text { protein complex assembly; cell surface receptor } \\
\text { linked signal transduction }\end{array}$ \\
\hline$C d 79 a$ & $\begin{array}{l}\text { CD79A antigen } \\
\text { (immunoglobulin-associated alpha) }\end{array}$ & 1418830_at & $\begin{array}{l}\text { immune response; cell surface receptor linked signal } \\
\text { transduction }\end{array}$ \\
\hline $\mathrm{Cr} 2+$ & complement receptor 2 & 1425289_a_at & $\begin{array}{l}\text { immune response; complement activation, classical } \\
\text { pathway }\end{array}$ \\
\hline$L t b$ & lymphotoxin B & 1419135_at & immune response; lymph node development \\
\hline Ppbpt, Cxcl7 & pro-platelet basic protein & 1418480_at & immune response \\
\hline SlamfI & $\begin{array}{l}\text { signaling lymphocytic activation molecule family } \\
\text { member I }\end{array}$ & 1425570_at & lymphocyte activation \\
\hline Tnfrsfl 3c & $\begin{array}{l}\text { tumor necrosis factor receptor superfamily, } \\
\text { member I3c }\end{array}$ & 1419307_at & $\begin{array}{l}\text { B cell homeostasis; positive regulation of germinal } \\
\text { center formation }\end{array}$ \\
\hline \multicolumn{4}{|c|}{ Inflammatory response and chemotaxis } \\
\hline $\mathrm{Ccl} 55^{\dagger}$ & chemokine ( $\mathrm{C}-\mathrm{C}$ motif) ligand 5 & 1418126_at & chemotaxis; inflammatory response \\
\hline Ccr2 & chemokine (C-C motif) receptor 2 & |42| I86_at & chemotaxis; inflammatory response \\
\hline Chstl & $\begin{array}{l}\text { carbohydrate (keratan sulfate Gal-6) } \\
\text { sulfotransferase I }\end{array}$ & |449|47_at & carbohydrate and galactose metabolic process \\
\hline Enpp2 & $\begin{array}{l}\text { ectonucleotide pyrophosphatase/ } \\
\text { phosphodiesterase } 2\end{array}$ & 1415894_at & chemotaxis; metabolic process \\
\hline S100a8 & SI00 calcium binding protein A8 & |419394_s_at & chemotaxis \\
\hline \multicolumn{4}{|c|}{ Protein synthesis and turnover } \\
\hline$C f d$ & complement factor D (adipsin) & |417867_at & proteolysis; immune response \\
\hline Gzma & granzyme A & 1417898_a_at & proteolysis; apoptosis \\
\hline \multicolumn{4}{|c|}{ Transcription, processing, and chromatin structure } \\
\hline Hipk2 & homeodomain interacting protein kinase 2 & 1429566_a_at & $\begin{array}{l}\text { negative regulation of transcription from RNA } \\
\text { polymerase II promoter }\end{array}$ \\
\hline Myst3 & MYST histone acetyltransferase 3 & |4363|5_at & nucleosome assembly \\
\hline SpiB & Spi-B transcription factor & 1460407_at & regulation of transcription, DNA-dependent \\
\hline
\end{tabular}

These genes were identified in the "Up-in-KO_tumor" profile (A) and "Down in WT tumor" profile (B) that are below the $\mathrm{p}$ value set for the DAVID analysis $(P<0.0001)$; see Additional file 2 , Table SI for the complete profile gene lists.

*Representative decreased genes from the "Down in WT tumor" profile for genes BALB tumors compared to BALBLsp-d tumors. These genes were identified after bioinformatic analysis filtering first on biological patterns using both Genespring and Spotfire Software followed by filtering on GO biological categories using the DAVID Bioinformatics Database. †Genes down-regulated $\geq 50 \%$ in BALB tumors compared to BALBLspd tumors based on GeneSpring. 
A.

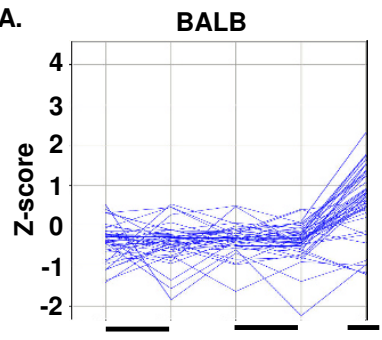

B.

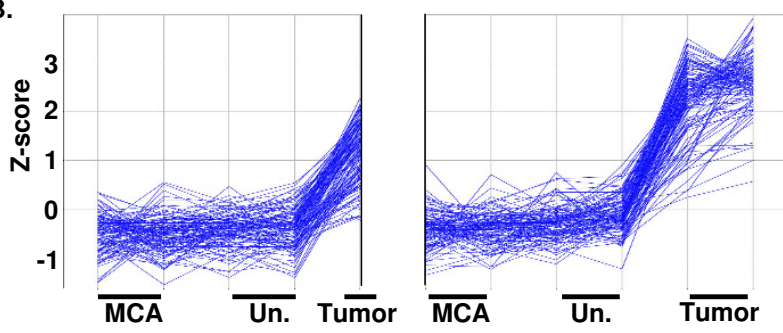

Figure 4

Analysis of protocol 2 genes increased in the BALBLps-d tumors compared to BALB tumors. Supervised and unsupervised bioinformatic methods were used for these analyses. A. Cluster 4 identified using statistical (Genespring) analysis. Each vertical line represents one sample for each strain for an $n=2$ (Un = uninvolved, MCA = 3-methlycholanthrene, and for BALBLps-d tumor) with the exception of BALB tumor $(n=I)$, indicated by the small horizontal black line above each treatment on the $\mathbf{x}$-axis. B. Profile (Spotfire) analysis similar to that of cluster 4. Z-score (y-axis) is the intensity in terms of standard deviations (SD) from the mean. The z-score is calculated by subtracting the mean and dividing by the SD for each probeset. See Additional file 6, Figure S3 for supervised and unsupervised analysis depicted as heat maps.

component factor i (Cfi), Ereg, kininogen 1 (Kng1), Spp1) that varied between the tumors in BALB and BALBLps-d mice, and three additional genes (parathyroid hormonelike peptide (Pthlh), claudin 2 (Cldn2), arginase 1 (Arg1)) that were highly, significantly upregulated in the BALBLpsd tumors compared to BALB tumors, but did not fall below the $\mathrm{p}$ value set for the DAVID analysis. Two genes in Table 1 from the early protocol (Ereg and Spp1) were also identified with Protocol 2 (late, progression stage) possibly indicating transcripts that are involved in both promotion and progression of tumorigenesis.

We then compared the summary GO categories for the genes identified using Protocol 1 (tumor promotion; early) and Protocol 2 (tumor progression; late). Pie charts illustrate the number of genes in each of 12 summary categories with altered transcript levels at early and advanced stages of carcinogenesis (Figure 6). This figure demonstrates an increase in the number of genes in cell growth, shape and protein synthesis and targeting, and transcrip- tion categories early in the response followed by a switch to more inflammation and immune responses, as well as apoptosis, protein synthesis, and cell growth, during the advanced stages of tumorigenesis.

To better understand the role of the microenvironment in the uninvolved tissue from tumor-bearing lungs in BALB and $\mathrm{BALB}^{\mathrm{L} p s d}$ mice, we then analyzed differential transcript expression in uninvolved tissue from tumor bearing lungs. Additional file 2, Table S1 contains those genes differentially expressed in uninvolved tissue between strains (all have $\mathrm{p}<0.05$ and two-fold or greater change in expression). The most dominant GO categories in BAL$\mathrm{B}^{\text {Lps- } d}$ uninvolved tissue were immune response $(p<$ $0.001)$ and immune system process $(p<0.005)$ with those genes upregulated $\geq 2$ fold in BALB ${ }^{L p s-d}$ uninvolved tissue compared to BALB uninvolved tissue (e.g. chemokine (C$\mathrm{C}$ motif) receptor 1 (Ccr2; $\mathrm{p}<0.05)$ (Additional file 2: Table S1, Tab A and Tab F). The major categories in BALB uninvolved tissue were hemopoietic cell lineage $(p<$ $0.004)$, immune system process $(p<0.015)$, leukocyte differentiation $(p<0.027)$ for those genes 50\% down-regulated (e.g. chemokine (C-C motif) ligand 5 ( $\mathrm{Ccl} 5$ ), CD3 antigen, delta polypeptide $(C d 3 d)$ ) compared to $\mathrm{BALB}^{\mathrm{L} p s-d}$ (Additional file 2: Table S1, Tab A and Tab E). The analysis of uninvolved tissue supports the above transcript analysis in micro-dissected tumors where more immune and inflammatory transcripts were elevated in BALB ${ }^{L p s d}$ and decreased in BALB mice.

\section{Discussion}

We previously demonstrated that lung carcinogenesis was enhanced in mice with dysfunctional Tlr4, likely due to greater chronic inflammation during tumor promotion in the Tlr4 mutant mice relative to the Tlr4 wild type strain [20]. In the present study, we found that TLR4 also protects against the inflammation observed during the advanced stages of tumorigenesis (see Figure 3) which supports our previous findings [20]. Using transcriptomics and integrative biology, we have also identified Tlr4modulated gene expression pathways that distinguish the tumor promotion stage (Protocol 1) and the progression stage (Protocol 2) of tumorigenesis. These novel Tlr4mediated pathways and gene signatures provide insight to the protective effect of TLR4 against lung carcinogenesis and may provide a means to develop diagnostic tests to identify individuals at risk for the disease.

We identified many novel genes with increased transcript levels in Tlr4-mutated mice (BALB ${ }^{L p s-d}$ ) after BHT. These include Ereg, heparin-binding EGF-like growth factor (Hbegf), high mobility group AT-hook 1 (Hmga1), myelocytomatosis oncogene $(M \gamma c), S p p 1$, and Tnc, and they are associated with GO categories that are consistent with 


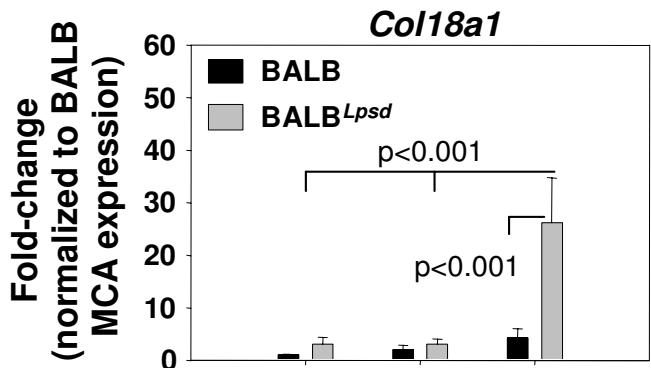

MCA Un. Tumor

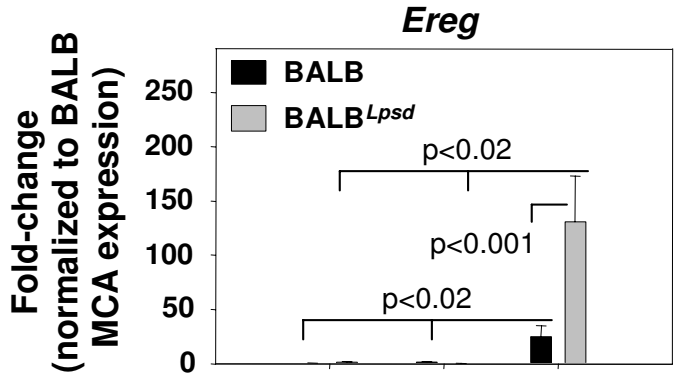

MCA Un. Tumor
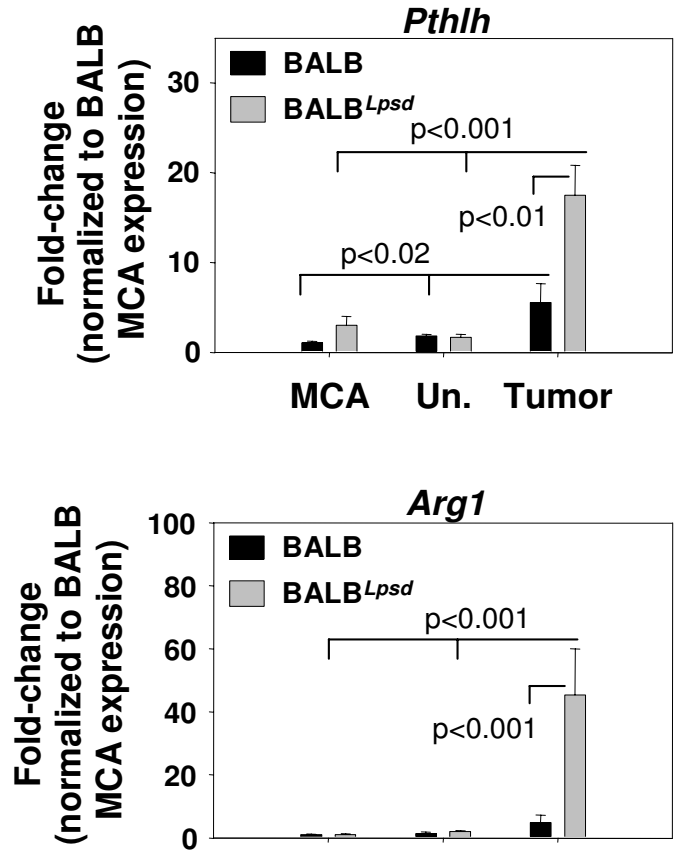

MCA Un. Tumor

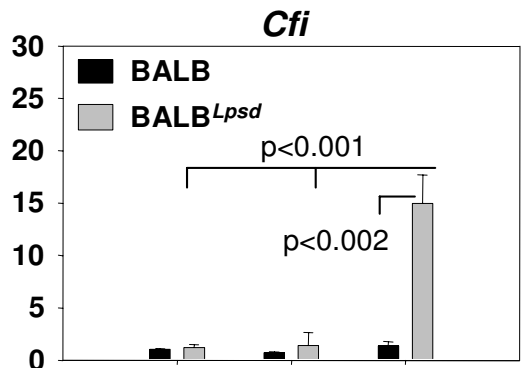

MCA Un. Tumor

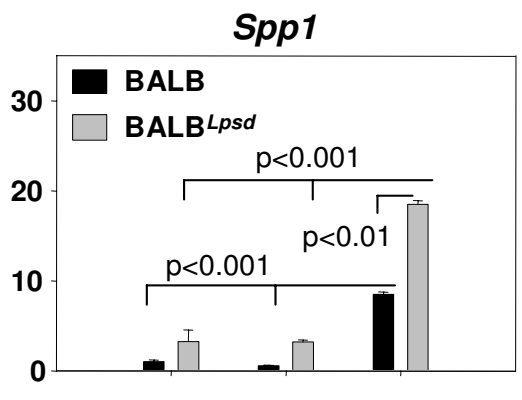

MCA Un. Tumor
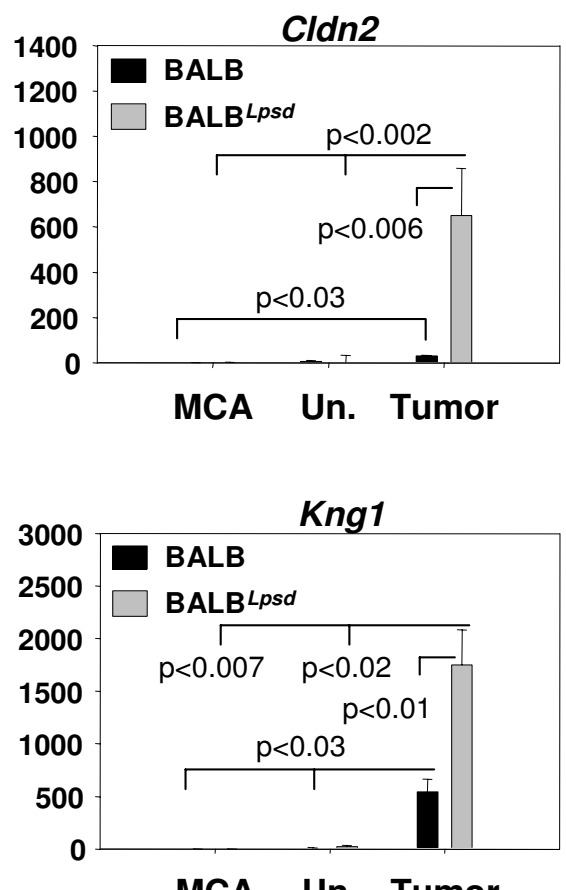

MCA Un. Tumor

Figure 5

Confirmation of select genes identified during progression (Protocol 2; MCA/BHT) in the BALB and BALBLps-d mice. These genes were selected based on the supervised microarray analysis in both strains 27 wks following MCA/BHT. Genes upregulated in the BALBLps-dmice compared to BALB mice. Mean and SEM are presented; $n=4-5$ mice/experimental group. $P$ values are indicated on the graphs for each gene; comparisons are between MCA/BHT treatment and MCA/oil controls or between BALB Lps-d compared to BALB mice. 


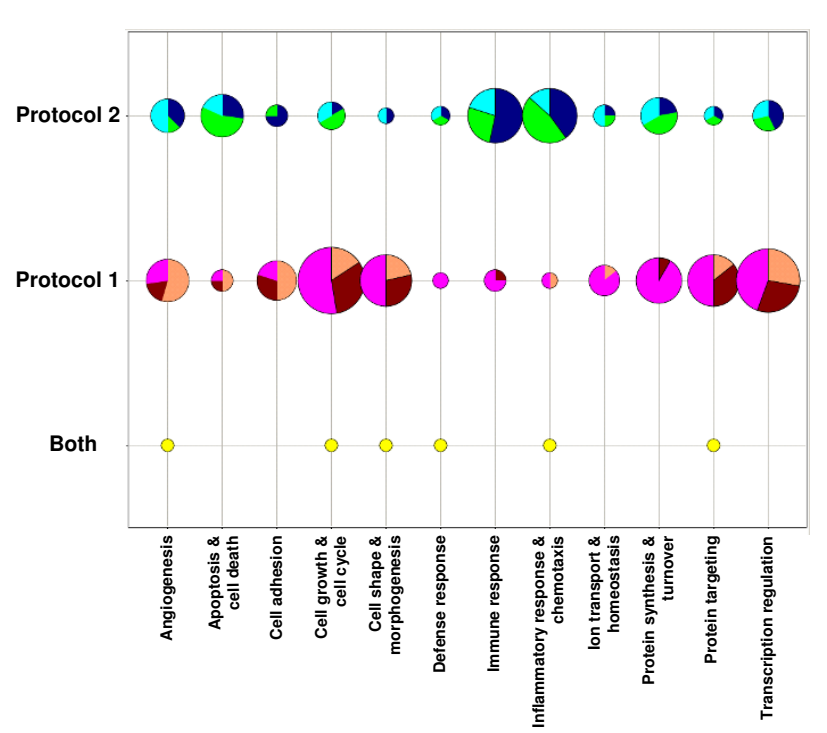

Figure 6

Pie chart comparison of the genes involved during early and late stages of carcinogenesis. Protocol I (promotion; Figure IA-B) and protocol 2 (advanced; Figure 4A-B) genes representing the major $\mathrm{GO}$ categories for these early and more advanced events during tumorigenesis are compared. Pie charts represent the number of genes in each group; largest circle contains 19 genes, the smallest I. Protocol 2 colors: Down_BALB_Tumor, navy; UP_BALB_Tumor, aqua; UP_BALBLps-d_Tumor, bright green. Protocol I colors: Down_BALB Lps-d_BHT_Idy, maroon; UP_BALBLps-d

_BHT_Idy, magenta; $\mathrm{BHT}$ _I day_BALB_recovery, orange.

Genes selected in both Protocols are in yellow.

early stages of carcinogenesis (cell cycle and growth, angiogenesis, protein synthesis and targeting, and transcription). Ereg and Hbegf are epidermal growth factor receptor (EGFR) ligands that can bind and activate the ERBB family of receptors [27]. EREG is an intratumoral marker for advanced NCSLC [28] and is upregulated in cancer cell lines [29,30]. Spp1 is a chemokine-like protein that appears to have a role in macrophage infiltration, among other functions [31], and has been identified as a lung AC biomarker [32]. Spp1 can also be activated by Kirstein ras proto-oncogene (K-RAS) in lung neoplasia [33]. Because Ereg and Spp1 (among others) are elevated at early (during promotion) and late (during progression) stages, these genes may play a role in the transition from initiated cell through promotion (adenomas) to progression (carcinomas).

Mutated Tlr4 caused increased inflammation in tumorbearing mice (Figure 3). The majority of the transcripts that were significantly decreased in the uninvolved tissue in the BALB mice compared to BALB ${ }^{L p s-d}$ mice were from genes involved in inflammation and immune responses, e.g. Ccl5 and Cd3d (Additional file 2, Table S1). Additionally, transcripts from immune response genes (such as Ccr2) were increased in the BALB ${ }^{L p s-d}$ uninvolved tissue compared to BALB uninvolved tissue. Thus, these data are consistent with the increased inflammation observed in the BALF from BALB ${ }^{\text {Lps-d }}$ mice (Figure 3). For example, CCR2 is the receptor for monocyte chemoattractant protein-1 (MCP-1) that modulates the innate immune response and recruits monocytes/macrophages to sites of inflammation [34]. In uninvolved tissue from the BALB ${ }^{L p s-}$ $d$ mice treated with MCA/BHT, we found a 1.5-fold increase in MCP-1 protein levels above MCA/oil controls compared to no increase in the BALB mice (preliminary ELISA analysis not shown). Because macrophages were recruited to the lungs but do not infiltrate the tumors [35], it is not surprising that chemokines specific to these cell types were upregulated in uninvolved tissue.

Some overlap in biological functions were found based on our analysis (see Fig 6). For example, GO categories for cell cycle and growth (Ereg), inflammation (Spp1), and development (ornithine decarboxylase $(O d c 1)$ ) contained genes identified in promotion and progression expression patterns for BALB ${ }^{L p s d}$ upregulated genes. Arg1 induces polyamine synthesis and hence proliferation, through ODC1 and was also significantly up-regulated in the BAL$\mathrm{B}^{\text {Lps- } d}$ tumors (Figure 5; [35]).

Based on the major GO categories identified, we propose that several key pathways are influenced by TLR4 deficiency during carcinogenesis (Figure 7). Many of the genes identified during promotion (e.g. Ereg, Hbegf, and Spp1) can signal through EGFR or are involved in EGFR signaling events which can then lead to cell growth and eventual tumor development (Figure 7A). Other genes inhibited by EGFR signaling, such as gap junction protein alpha 1 (Gja1), a mediator for cell-cell communication in lung epithelial cells that is down-regulated in human and mouse lung cancer [36,37], were elevated in the BALB mice (Gja1, confirmed by PCR, data not shown). Thus, during promotion, the EGFR pathway may drive the proliferative response in the Tlr4 mutant mice while inhibiting cell-cell communication, which provides a growth advantage for the initiated cells. During progression (Figure $7 \mathrm{~B}$ ), many inflammation, chemotactic and immune response genes were elevated in the BALB ${ }^{L p s-d}$ mice and decreased in the BALB mice, likely providing a more aggressive microenvironment for tumor growth. At the same time, several proliferative pathways were elevated in the BALB ${ }^{L p s}-d$ mice (e.g. EGFR), further increasing the chance of tumor growth and progression. Thus, based on our analysis of pathways downstream of TLR4 or those downstream of mice lacking TLR4, it will be important to 
A.

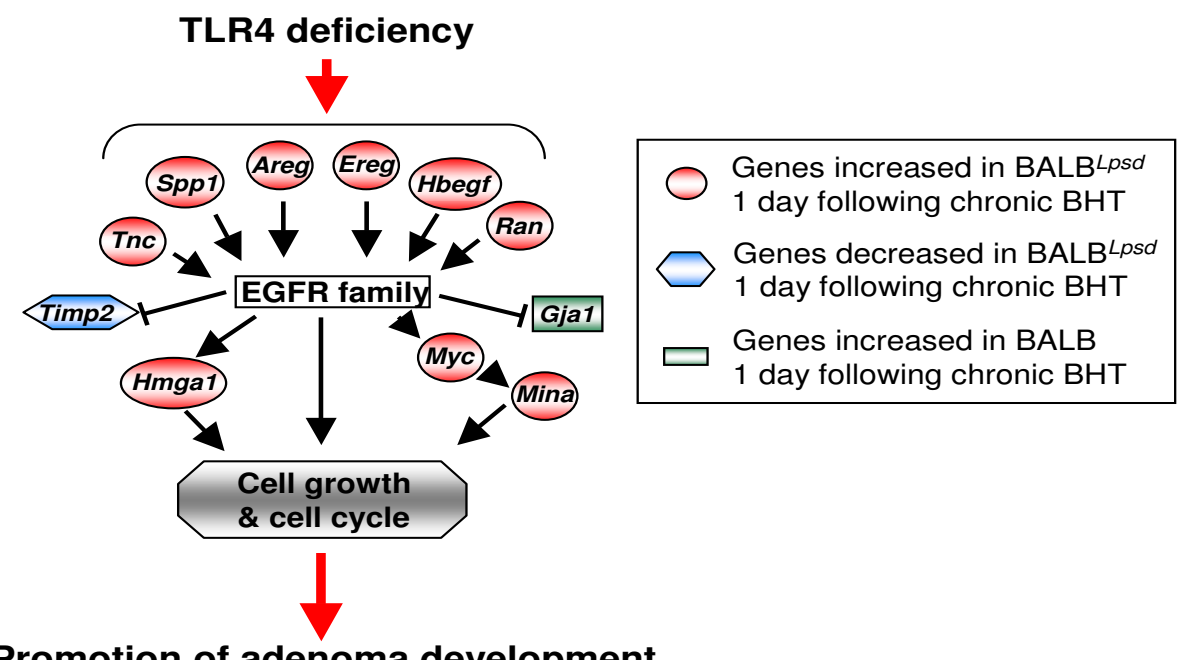

Promotion of adenoma development

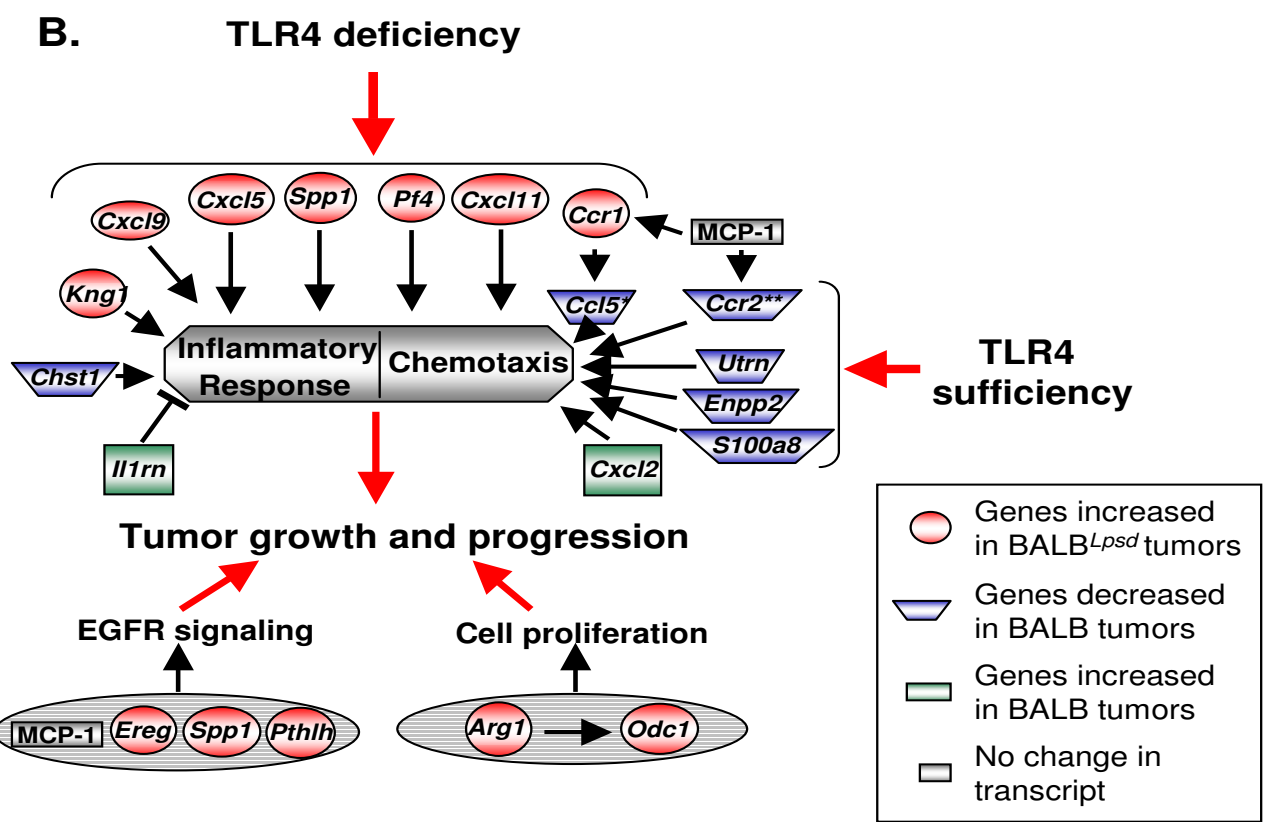

\section{Figure 7}

Proposed pathways for promotion (A) and progression genes (B) influenced by TLR4. A. Promotion genes primarily signal through or are involved in EGFR signaling which may lead to cell growth and eventual tumor development. Thus, the EGFR pathway may drive the proliferative response in mice deficient in Tlr4 and concurrently inhibit communication between cells (Gjal), thus providing a growth advantage. References for gene interactions not described in text: Ran, [49]; Myc, [50]; Hmag I, [5I]; Tnc, [52]; Mina, [53], Timp2 [54]. Symbols: red, genes increased in BALBLps-d mice I day Protocol I; blue, genes decreased in BALBLps-d mice I day Protocol; green, genes increased in BALB mice I day Protocol I. B. During progression, the combination of inflammation observed in BALBLps-d mice in concert with up-regulation of these and other immune response genes, the many inflammation and immune response genes that were down regulated in BALB mice, and the additional contribution of cell growth genes (e.g. SPPI; [3 I], MCP-I; [55], supports a role of TLR4 in protection against lung tumor progression. Symbols: red, genes increased in BALB Lps-d tumors; blue, genes decreased in BALB tumors; green, genes increased in BALB tumors; grey, protein changes in uninvolved tissue from the BALB ${ }^{L p s-d}$ mice. *Also decreased in BALB uninvolved tissue; **Also increased in BALBLps-d uninvolved tissue. Abbreviations: Ccr2, chemokine (C-C motif) receptor I; Chstl, carbohydrate sulfotransferase I, Cxcl2, chemokine (C-X-C motif) ligand 2; Enpp2, ectonucleotide phosphodiesterase 2; III rn, interleukin I receptor antagonist; SI00a8, SI00 calcium binding protein A8; Timp2, tissue inhibitor of metalloproteinases; Utrn, utrophin. 
focus future studies on these specific pathways to further elucidate the mechanisms of TLR4-mediated protection against BHT-induced inflammation and tumor promotion, as the two phenomena are certainly linked. However, other genes that were over the set $\mathrm{p}$ value for the DAVID analysis with the progression study (and thus not found in Tables 3 and 4) but that were identified in the "up_KO_tumor" profile, provide additional evidence for similarities between the early and advanced stages of carcinogenesis. For example, Pthlh (Figure 5) is located in the pulmonary adenoma susceptibility 1 (Pas1) gene cluster near Kras on mouse chromosome 6 [38]. Pthlh is also associated with decreased survival in lung AC patients [39] possibly through EGFR ligand activation [33]. In addition, PTHLH induces MCP-1 in prostate cancer which can lead to increased proliferation [40].

Several investigations have characterized gene transcripts in human and mouse lung AC [25,41-45]. Stearman et al. [25] compared human and mouse genes responsible for lung $\mathrm{AC}$; one gene identified was (Spp1) that was increased in BALB Bps-d $^{-d}$ during both protocols (Tables 1, 2, 3 and 4). However, several other genes in our study were either significantly upregulated (such as Tyms, thymidylate synthase) or downregulated (such as Aldh1a1, aldehyde dehydrogenase 1a1, and Vwf, Von Willebrand factor) in the tumors from both strains (all $\geq 2$-fold or $\geq$ $50 \% ; \mathrm{p}<0.05)$, similar to the A/J mice used by Stearman et al. These genes may be more general markers of advanced stages of tumorigenesis and their identification in our study supports the comparison between species and strain. The mouse lung $\mathrm{AC}$ model was similar to human $\mathrm{AC}$ in the molecular changes that occurred during carcinogenesis [25]. In a microarray study using K-ras over-expressing mice, Ereg was identified as a significantly upregulated transcript in lung tumors [43], which also supports our results. Additional human microarray studies that assessed lung tissue from smokers [44], and tumor tissue from patients with $\mathrm{AC}$ and squamous cell carcinoma, another NSCLC, identified other unique genes $[41,42,45]$ such as Cdkn1a, cyclin-dependent kinase inhibitor 1A (P21), up in BALB ${ }^{\text {Lps-d }}$ (Table 1). Thus, a number of the genes identified in the present study were also identified in human studies and were all associated with either inflammation or cell growth. However, due to the specific TLR4 focus in our model, as well as differences in tumor histology and grade, tumor size, node status, and margin status, many of the genes we identified were not found in these human and mouse microarray studies. In addition, the numbers of the presumptive bronchioalveolar stem cells (BASCs) expressing both a type II cell (prosurfactant apoprotein C; SPC) and Clara cell specific marker (Clara cell $10 \mathrm{kD}$ protein; CC10) may also influence gene expression in these different models [46].

\section{Conclusion}

In summary, based on our transcriptome analysis, the protective effect of TLR4 in lung carcinogenesis involves inhibition of multiple pathways, many of which overlap and likely interact, such as the EGFR and PTHLH pathways (Figure 7). EGFR activating mutations in human NSCLC correlates to positive Gefitinib (EGFR kinase inhibitor) responsiveness, thus deficiency in TLR4 in humans may further activate this pathway $[47,48]$. These studies have identified a novel panel of genes differentially expressed in mice with sufficient or deficient TLR4 during tumor promotion (such as those genes up-regulated in BALB Lps-d: amphiregulin (Areg), Ereg, Hbegf, Hmga1, Myc, myc induced nuclear antigen (Mina), rasrelated nuclear protein (Ran), Spp1, and Tnc; see Figure 7A) and during progression stages of tumorigenesis (such as genes up-regulated in BALB ${ }^{L p s-d}$ tumors: Arg1, chemokine (C-C motif) receptor 1 (Ccr1), platelet factor 4 (Pf4), chemokine (C-X-C motif) ligand 5 (Cxcl5), Cxcl9, Cxcl11, Ereg, Kng1, Odc1, Pthlh, and Spp1, see Figure 7B). These gene panels for early and advanced stages of tumorigenesis may be predictive determinants for tumor susceptibility in those individuals with altered innate immune systems. The mouse model will allow us to test the significance of these genes in lung $\mathrm{AC}$ using in vivo and in vitro molecular techniques, such as transgenic or knock-out mice/cells, as well as siRNA, in order to elucidate additional pathways to target for future therapies. In addition, these gene profiles may aid in our understanding of those individuals occupationally exposed to endotoxin who appear to have reduced lung cancer risk [15-17].

\section{Competing interests}

The authors declare that they have no competing interests.

\section{Authors' contributions}

AKB designed and performed the mouse experiments including collecting and analyzing data, RNA isolation, Genespring analysis, PCR, and wrote the manuscript. J. Fostel performed the unsupervised microarray analysis with Spotfire and assisted in writing the manuscript. LMD and CW assisted in the mouse experiments. EAR performed data analysis. SFG performed the microarray analyses, from RNA purity testing to hybridization and array scanning. JF assisted in the immunohistochemical staining. SRK assisted in the microarray bioinformatic analysis and the writing of the manuscript. All authors read and approved the final manuscript. 


\section{Additional material}

\section{Additional file 1}

Additional Figure 1. Experimental design. A) Protocol 1 (Promotion stage) involved exposure to BHT (150-200 $\mathrm{mg} / \mathrm{kg} /$ week) or oil control in four weekly ip injections. Mice were sacrificed 1 and 3 days following the last dose of BHT and processed for BAL analysis and RNA extraction. B) Protocol 2 (Progression stage) involved a single injection of the initiator MCA $(10 \mathrm{~g} / \mathrm{g})$ followed by 6 weekly ip injections of either BHT (125-200 $\mathrm{mg} / \mathrm{kg} /$ week; "promoter") or oil. Mice were sacrificed 27 weeks following the MCA exposure. Tumors and adjacent uninvolved tissue were microdissected for transcriptomic analysis, as well as assessment of pulmonary inflammation by BAL analysis and histology.

Click here for file

[http://www.biomedcentral.com/content/supplementary/14764598-8-107-S1.PPT]

\section{Additional file 2}

Additional Table 1: A comprehensive compilation of all the data used for the analyses. A) All microarray probes (Tab A) and profile(s) to which they were assigned. Flag columns: early clusters (columns $D, E, L$, $M, N$ ); late clusters (columns $F, G, H, I, J, K)$. Data columns: BHT_1day up_KO_supervised $(L)=$ early pattern (cluster 3$)$, genes upregulated early in BALB ${ }^{\text {Lpsd }} 1$ day following BHT vs. BALB; BHT_1day

up_KO_unsupervised (E), genes with similar patterns as cluster 3 early (L); BHT_1day down_KO_supervised $(M)=$ cluster 4 early, genes downregulated early ( 1 day following $B H T$ ) in BALB ${ }^{\text {Lpsd }} v$ s. BALB;

BHT_1day_down_KO_unsupervised (D), patterns similar to cluster 4 early (M); BHT_WT_recovery_unsupervised $(\mathrm{N})$ genes with late recovery BALB ${ }^{\text {Lpsd; }}$ Up_WT_tumor_supervised $(F)=$ cluster 1 late, genes upregulated in BALB tumors vs. BALB ${ }^{\mathrm{Lpsd}}$; Up_WT_tumor_unsupervised (J), patterns similar to cluster 1 late $(F)$; Up_KO_tumor_supervised $(G)=$ cluster 4 late, genes up-regulated in BALB ${ }^{\text {Lpsd }}$ tumors vs. BALB; Up_KO_tumor_unsupervised (H), patterns similar to cluster 4 late $(G)$; Down_WT_tumor-supervised $(K)=$ cluster 5 late, genes down-regulated in BALB tumors vs. BALB Lpsd; Down_WT_tumor_unsupervised (I), patterns similar to cluster 5 late (K). Uninvolved genes: increased or decreased in BALB uninvolved tissue vs. BALB ${ }^{\mathrm{Lpsd}}(B)$; increased or decreased in BALB ${ }^{\text {Lpsd }}$ uninvolved vs. BALB (C). B) DAVID analysis genes (Tab B) enrichment criteria: p values below $3 \times 10^{-4}$ (protocol 1, early genes) and $1 \times 10^{-4}$ (protocol 2, late genes); non-specific categories (>100 genes) not included. Categories based on primary and secondary biological significance (D and E, respectively). C. DAVID analysis (Tab C), protocol 1 early genes based on combination in columns $D, E, L, M$, and N (Tab A). Red font = GO categories for selected analysis (SM Table $1 B) ;$ yellow = categories not included. D. DAVID analysis (Tab D), protocol 2 late genes based on combination in columns $F, G, H, I, J$, and $K$ (Tab A). Color scheme as described in C. E. DAVID analysis, protocol 2 uninvolved BALB genes (Tab A, column B). F. DAVID analysis, protocol 2 uninvolved BALB $B^{\mathrm{Lps} d}$ genes in A (Tab A, column C).

Click here for file

[http://www.biomedcentral.com/content/supplementary/14764598-8-107-S2.ZIP]

\section{Additional file 3}

Additional Methods for the Affymetrix Mouse 430A_MOE array analysis. Detailed methodology for the microarray analysis studies.

Click here for file

[http://www.biomedcentral.com/content/supplementary/14764598-8-107-S3.DOC]

\section{Additional file 4}

Additional Table 2. Primer pairs used for the QRT-PCR analysis as described in methods, for Figs. 2 and 5.

Click here for file

[http://www.biomedcentral.com/content/supplementary/14764598-8-107-S4.DOC]

\section{Additional file 5}

Additional Figure 2: Heat maps of the same representative gene lists identified for protocol 1 depicted in Figure 1. A) Expression pattern for cluster 3 (BHT_1day up_KO) identified from supervised analysis in chronic BHT-treated BALB and BALB ${ }^{\mathrm{Lpsd}}$ mice over a time course (oil, 1 and 3 days following BHT). Each column represents an individual animal. From left to right, columns 2,3,6 = BALB, oil; columns 1,4,5= $B A L B, 3 d y$ BHT; columns 13-15 = BALB, 1 dy BHT; columns 7-9 = BALB ${ }^{\text {Lpsd }}$, oil; columns 10-12 = BALB ${ }^{\text {Lpsd }}, 3$ dy BHT; columns 16-18 = $B A L B^{\text {Lpsd, }} 1 d y$ BHT. B) Unsupervised analysis resulting in similar expression patterns to that identified in (A). From left to right, columns 1-3 = BALB, oil; columns 4-6 = BALB ${ }^{\mathrm{Lpsd}}$, oil; columns 7-9 = BALB, $3 d y$ BHT; columns 10-12 = BALB Lpsd, 3 dy BHT; columns 13-15 = BALB, 1 $d y$ BHT; columns $16-18=B A L B^{\text {Lpsd }}, 1 d y B H T . N=3$ per treatment group for each strain. $Y$-axis is the probeset.

Click here for file

[http://www.biomedcentral.com/content/supplementary/14764598-8-107-S5.PPT]

\section{Additional file 6}

Additional Figure 3: Heat maps of the same representative gene lists identified from protocol 2 depicted in Figure 4. A) Expression pattern for cluster 4 (Up_KO_tumor) identified by supervised analysis. From left to right, columns 1-2 = BALB ${ }^{\mathrm{Lspd}}, \mathrm{MCA} / \mathrm{BHT}$-induced tumor tissue; column $3=B A L B, M C A / B H T-i n d u c e d$ tumor tissue; columns $4-5=B A L-$ $B^{\mathrm{Lspd}}, M C A / B H T-i n d u c e d$ uninvolved tissue; columns 6-7 $=B A L B^{\mathrm{Lspd}}$, MCA exposed tissue; columns 8, $11=B A L B, M C A$ exposed tissue; columns 9-10 = BALB, MCA/BHT-induced uninvolved tissue. B) Unsupervised analysis with similar gene expression patterns to that observed in (A). From left to right, column $1=B A L B, M C A / B H T$-induced tumor tissue; columns 2-3 = BALB Lspd, $M C A / B H T$-induced tumor tissue; columns 4-5, BALB ${ }^{\text {Lspd }}, M C A / B H T$-induced uninvolved tissue; columns $6,10=$ BALB Lspd, MCA exposed tissue; columns 7-8, BALB, MCA/BHT-induced uninvolved tissue; columns 10-11 = BALB, MCA exposed tissue. $N=2$ per treatment group, except BALB tumor $(n=1)$. Y-axis is the probeset. Click here for file

[http://www.biomedcentral.com/content/supplementary/14764598-8-107-S6.PPT]

\section{Acknowledgements}

The authors would like to thank Drs. Alex Merrick and Pierre Bushel for critically reviewing the manuscript. J Fostel was supported by the Division of Intramural Research of the NIEHS contract HHSN273200700046U. S.R.K., L.M.D., C.W., J.F. and S.F.G. were supported by the Division of Intramural Research of the National Institute of Environmental Health Science. A.K.B. and E.A.R. were supported by Michigan State University internal funds.

\section{References}

I. Schottenfeld D: Etiology and Epidemiology of Lung Cancer. In Lung Cancer- Principles and Practice 2nd edition. Edited by: Pass HI, 
Mitchell JB, Johnson DH, Turrisi AT, Minna JD. Philadelphia: Lippincott Williams and Wilkins; 2000:367-388.

2. Bauer AK, Malkinson AM, Kleeberger SR: Susceptibility to neoplastic and non-neoplastic pulmonary diseases in mice: genetic similarities. Am J Physiol Lung Cell Mol Physiol 2004, 287:L685-703.

3. Cohen BH, Diamond EL, Graves CG, Kreiss P, Levy DA, Menkes HA, Permutt S, Quaskey S, Tockman MS: A common familial component in lung cancer and chronic obstructive pulmonary disease. Lancet 1977, 2:523-526.

4. Mayne ST, Buenconsejo J, Janerich DT: Previous lung disease and risk of lung cancer among men and women nonsmokers. Am J Epidemiol 1999, 149:13-20.

5. Vesterinen E, Pukkala E, Timonen T, Aromaa A: Cancer incidence among 78,000 asthmatic patients. Int J Epidemiol 1993, 22:976-982.

6. Malkinson AM: Molecular comparison of human and mouse pulmonary adenocarcinomas. ExpLung Res 1998, 24:54|-555.

7. Bauer AK, Dwyer-Nield LD, Keil K, Koski K, Malkinson AM: Butylated hydroxytoluene (BHT) induction of pulmonary inflammation: a role in tumor promotion. Exp Lung Res 200I, 27:197-216.

8. Malkinson AM, Radcliffe RA, Bauer AK: Quantitative trait locus mapping of susceptibilities to butylated hydroxytolueneinduced lung tumor promotion and pulmonary inflammation in CXB mice. Carcinogenesis 2002, 23:4II -4I7.

9. Malkinson AM, Koski KM, Evans WA, Festing MF: Butylated hydroxytoluene exposure is necessary to induce lung tumors in BALB mice treated with 3-methylcholanthrene. Cancer Res 1997, 57:2832-2834.

10. Witschi H, Malkinson AM, Thompson JA: Metabolism and pulmonary toxicity of butylated hydroxytoluene. In Metabolic Activation and Toxicity of Chemical Agents to Lung Tissue and Cells Edited by: Gram TE. United Kingdom: Pergamon Press; 1993: I85-2I2.

II. Poltorak A, He X, Smirnova I, Liu MY, Huffel CV, Du X, Birdwell D, Alejos E, Silva M, Galanos C, Freudenberg M, Ricciardi-Castagnoli P, Layton B, Beutler B: Defective LPS signaling in $\mathrm{C} 3 \mathrm{H} / \mathrm{HeJ}$ and C57BL/IOScCr mice: mutations in TIr4 gene. Science 1998, 282:2085-2088

12. Kleeberger SR, Reddy S, Zhang LY, Jedlicka AE: Genetic susceptibility to ozone-induced lung hyperpermeability: role of tolllike receptor 4. Am J Respir Cell Mol Biol 2000, 22:620-627.

13. Zhang X, Shan P, Qureshi S, Homer R, Medzhitov R, Noble PW, Lee PJ: Cutting edge: TLR4 deficiency confers susceptibility to lethal oxidant lung injury. I Immunol 2005, I 75:4834-4838.

14. Hollingsworth JW, Whitehead GS, Lin KL, Nakano H, Gunn MD, Schwartz DA, Cook DN: TLR4 signaling attenuates ongoing allergic inflammation. J Immunol 2006, 176:5856-5862.

15. Astrakianakis G, Seixas NS, Ray R, Camp JE, Gao DL, Feng Z, Li W, Wernli KJ, Fitzgibbons ED, Thomas DB, Checkoway H: Lung cancer risk among female textile workers exposed to endotoxin. J Natl Cancer Inst 2007, 99:357-364.

16. Laakkonen A, Kyyronen P, Kauppinen T, Pukkala El: Occupational exposure to eight organic dusts and respiratory cancer among Finns. Occup Environ Med 2006, 63:726-733.

17. Mastrangelo G, Grange JM, Fadda E, Fedeli U, Buja A, Lange JH: Lung cancer risk: effect of dairy farming and the consequence of removing that occupational exposure. Am J Epidemiol 2005, 16I:1037-1046.

18. Hold GL, Rabkin CS, Chow WH, Smith MG, Gammon MD, Risch HA, Vaughan TL, McColl KE, Lissowska J, Zatonski W, Schoenberg JB, Blot WJ, Mowat NA, Fraumeni JF Jr, El-Omar EM: A functional polymorphism of toll-like receptor 4 gene increases risk of gastric carcinoma and its precursors. Gastroenterology 2007, | 32:905-9|2.

19. Yusuf N, Nasti TH, Long JA, Naseemuddin M, Lucas AP, Xu H, Elmets $C A$ : Protective role of Toll-like receptor 4 during the initiation stage of cutaneous chemical carcinogenesis. Cancer Res 2008, 68:615-622.

20. Bauer AK, Dixon D, DeGraff LM, Cho HY, Walker CR, Malkinson AM, Kleeberger SR: Toll-like receptor 4 in butylated hydroxytoluene-induced mouse pulmonary inflammation and tumorigenesis. I Natl Cancer Inst 2005, 97: 1778-I78I.

21. Vogel SN, Wax JS, Perera PY, Padlan C, Potter M, Mock BA: Construction of a BALB/c congenic mouse, C.C3H-Lpsd, that expresses the Lpsd allele: analysis of chromosome $\mathbf{4}$ markers surrounding the Lps gene. Infect Immun 1994, 62:4454-4459.

22. Brown LM, Malkinson AM, Rannels DE, Rannels SR: Compensatory lung growth after partial pneumonectomy enhances lung tumorigenesis induced by 3-methylcholanthrene. Cancer Res 1999, 59:5089-5092.

23. Bauer AK, Dwyer-Nield LD, Malkinson AM: High cyclooxygenase I (COX-I) and cyclooxygenase 2 (COX-2) contents in mouse lung tumors. Carcinogenesis 2000, $21: 543-550$.

24. Hernandez LG, Forkert PG: Inhibition of vinyl carbamateinduced lung tumors and Kras2 mutations by the garlic derivative diallyl sulfone. Mutat Res 2009, 662:16-21.

25. Stearman RS, Dwyer-Nield L, Zerbe L, Blaine SA, Chan Z, Bunn PA Jr, Johnson GL, Hirsch FR, Merrick DT, Franklin WA, Baron AE, Keith RL, Nemenoff RA, Malkinson AM, Geraci MW: Analysis of orthologous gene expression between human pulmonary adenocarcinoma and a carcinogen-induced murine model. Am J Pathol 2005, 167:1763-1775.

26. Cho HY, Jedlicka AE, Reddy SP, Kensler TW, Yamamoto M, Zhang LY, Kleeberger SR: Role of NRF2 in protection against hyperoxic lung injury in mice. Am J Respir Cell Mol Biol 2002, 26: I75- 182.

27. Katoh $Y$, Katoh M: Canonical WNT signaling pathway and human AREG. Int J Mol Med 2006, 17:1 163-1166.

28. Zhang J, Iwanaga K, Choi KC, Wislez M, Raso MG, Wei W, Wistuba II, Kurie JM: Intratumoral epiregulin is a marker of advanced disease in non-small cell lung cancer patients and confers invasive properties on EGFR-mutant cells. Cancer Prev Res (Phila Pa) 2008, I:20I-207.

29. Baba I, Shirasawa S, Iwamoto R, Okumura K, Tsunoda T, Nishioka M, Fukuyama K, Yamamoto K, Mekada E, Sasazuki T: Involvement of deregulated epiregulin expression in tumorigenesis in vivo through activated Ki-Ras signaling pathway in human colon cancer cells. Cancer Res 2000, 60:6886-6889.

30. Toyoda H, Komurasaki T, lkeda $\mathrm{Y}$, Yoshimoto M, Morimoto $\mathrm{S}$. Molecular cloning of mouse epiregulin, a novel epidermal growth factor-related protein, expressed in the early stage of development. FEBS Lett 1995, 377:403-407.

31. Nomiyama T, Perez-Tilve D, Ogawa D, Gizard F, Zhao Y, Heywood EB, Jones KL, Kawamori R, Cassis LA, Tschop MH, Bruemmer D: Osteopontin mediates obesity-induced adipose tissue macrophage infiltration and insulin resistance in mice. J Clin Invest 2007, II 7:2877-2888.

32. Hu Z, Lin D, Yuan J, Xiao T, Zhang H, Sun W, Han N, Ma Y, Di X, Gao M, Ma J, Zhang J, Cheng S, Gao Y: Overexpression of osteopontin is associated with more aggressive phenotypes in human non-small cell lung cancer. Clin Cancer Res 2005, I I:4646-4652.

33. Cho YM, Lewis DA, Koltz PF, Richard V, Gocken TA, Rosol TJ, Konger RL, Spandau DF, Foley J: Regulation of parathyroid hormone-related protein gene expression by epidermal growth factor-family ligands in primary human keratinocytes. J Endocrinol 2004, 181 : 179-190.

34. Boring L, Gosling J, Chensue SW, Kunkel SL, Farese RV Jr, Broxmeyer HE, Charo IF: Impaired monocyte migration and reduced type I (ThI) cytokine responses in C-C chemokine receptor 2 knockout mice. / Clin Invest 1997, 100:2552-256I.

35. Redente EF, Orlicky DJ, Bouchard RJ, Malkinson AM: Tumor signaling to the bone marrow changes the phenotype of monocytes and pulmonary macrophages during urethane-induced primary lung tumorigenesis in A/J mice. Am J Pathol 2007, 170:693-708.

36. Avanzo JL, Mesnil M, Hernandez-Blazquez FJ, Mackowiak II, Mori CM da Silva TC, Oloris SC, Garate AP, Massironi SM, Yamasaki H, Dagli ML: Increased susceptibility to urethane-induced lung tumors in mice with decreased expression of connexin 43. Carcinogenesis 2004, 25: 1973-1982.

37. Johnson LN, Koval M: Cross-talk between pulmonary injury, oxidant stress, and gap junctional communication. Antioxid Redox Signal 2009, I I:355-367.

38. Manenti G, Galbiati F, Noci S, Dragani TA: Outbred CD-I mice carry the susceptibility allele at the pulmonary adenoma susceptibility I (Pas I) locus. Carcinogenesis 2003, 24: | | 43-I| 48.

39. Manenti G, De Gregorio L, Pilotti S, Falvella FS, Incarbone M, Ravagnani F, Pierotti MA, Dragani TA: Association of chromosome I 2p genetic polymorphisms with lung adenocarcinoma risk and prognosis. Carcinogenesis 1997, 18:1917-1920. 
40. Lu Y, Xiao G, Galson DL, Nishio Y, Mizokami A, Keller ET, Yao Z, Zhang J: PTHrP-induced MCP-I production by human bone marrow endothelial cells and osteoblasts promotes osteoclast differentiation and prostate cancer cell proliferation and invasion in vitro. Int J Cancer 2007, I $21: 724-733$.

41. Beer DG, Kardia SL, Huang CC, Giordano TJ, Levin AM, Misek DE, Lin L, Chen G, Gharib TG, Thomas DG, Lizyness ML, Kuick R, Hayasaka S, Taylor JM, lannettoni MD, Orringer MB, Hanash S: Geneexpression profiles predict survival of patients with lung adenocarcinoma. Nat Med 2002, 8:816-824.

42. Landi MT, Dracheva T, Rotunno M, Figueroa JD, Liu H, Dasgupta A, Mann FE, Fukuoka J, Hames M, Bergen AW, Murphy SE, Yang P, Pesatori AC, Consonni D, Bertazzi PA, Wacholder S, Shih JH, Caporaso NE, Jen J: Gene expression signature of cigarette smoking and its role in lung adenocarcinoma development and survival. PLOS ONE 2008, 3:el65I.

43. Lee S, Kang J, Cho M, Seo E, Choi H, Kim E, Kim J, Kim H, Kang GY, Kim KP, Park YH, Yu DY, Yum YN, Park SN, Yoon DY: Profiling of transcripts and proteins modulated by K-ras oncogene in the lung tissues of K-ras transgenic mice by omics approaches. Int J Oncol 2009, 34: 161-172.

44. Spira A, Beane JE, Shah V, Steiling K, Liu G, Schembri F, Gilman S, Dumas YM, Calner P, Sebastiani P, Sridhar S, Beamis J, Lamb C, Anderson T, Gerry N, Keane J, Lenburg ME, Brody JS: Airway epithelial gene expression in the diagnostic evaluation of smokers with suspect lung cancer. Nat Med 2007, 13:36 I-366.

45. Sun Z, Wigle DA, Yang P: Non-overlapping and non-cell-typespecific gene expression signatures predict lung cancer survival. J Clin Oncol 2008, 26:877-883.

46. Kim CF, Jackson EL, Woolfenden AE, Lawrence S, Babar I, Vogel S, Crowley D, Bronson RT, jacks T: Identification of bronchioalveolar stem cells in normal lung and lung cancer. Cell 2005, | 21:823-835.

47. Paez JG, Janne PA, Lee JC, Tracy S, Greulich H, Gabriel S, Herman P, Kaye FJ, Lindeman N, Boggon TJ, Naoki K, Sasaki H, Fujii Y, Eck MJ, Sellers WR, Johnson BE, Meyerson M: EGFR mutations in lung cancer: correlation with clinical response to gefitinib therapy. Science 2004, 304: 1497-1500.

48. Sordella R, Bell DW, Haber DA, Settleman J: Gefitinib-sensitizing EGFR mutations in lung cancer activate anti-apoptotic pathways. Science 2004, 305: I 163-1167.

49. Jayachandran G, Sazaki J, Nishizaki M, Xu K, Girard L, Minna JD, Roth JA, Ji L: Fragile histidine triad-mediated tumor suppression of lung cancer by targeting multiple components of the Ras/ Rho GTPase molecular switch. Cancer Res 2007, 67:10379-10388.

50. Ehrhardt A, Bartels T, Geick A, Klocke R, Paul D, Halter R: Development of pulmonary bronchiolo-alveolar adenocarcinomas in transgenic mice overexpressing murine c-myc and epidermal growth factor in alveolar type II pneumocytes. BrJ Cancer 200I, 84:8I3-8I8.

51. Holth LT, Thorlacius AE, Reeves R: Effects of epidermal growth factor and estrogen on the regulation of the HMG-I/Y gene in human mammary epithelial cell lines. DNA Cell Biol 1997, 16:1299-1309.

52. Swindle CS, Tran KT, Johnson TD, Banerjee P, Mayes AM, Griffith L, Wells $A$ : Epidermal growth factor (EGF)-like repeats of human tenascin-C as ligands for EGF receptor. J Cell Biol 200I, 154:459-468.

53. Tsuneoka M, Koda Y, Soejima M, Teye K, Kimura H: A novel myc target gene, mina53, that is involved in cell proliferation. J Biol Chem 2002, 277:35450-35459.

54. Nutt JE, Lazarowicz HP, Mellon JK, Lunec J: Gefitinib ('Iressa', ZD I 839) inhibits the growth response of bladder tumour cell lines to epidermal growth factor and induces TIMP2. Br J Cancer 2004, 90: 1679-1685.

55. Zhu J, Jia X, Xiao G, Kang Y, Partridge NC, Qin L: EGF-like ligands stimulate osteoclastogenesis by regulating expression of osteoclast regulatory factors by osteoblasts: implications for osteolytic bone metastases. J Biol Chem 2007, 282:26656-26664.

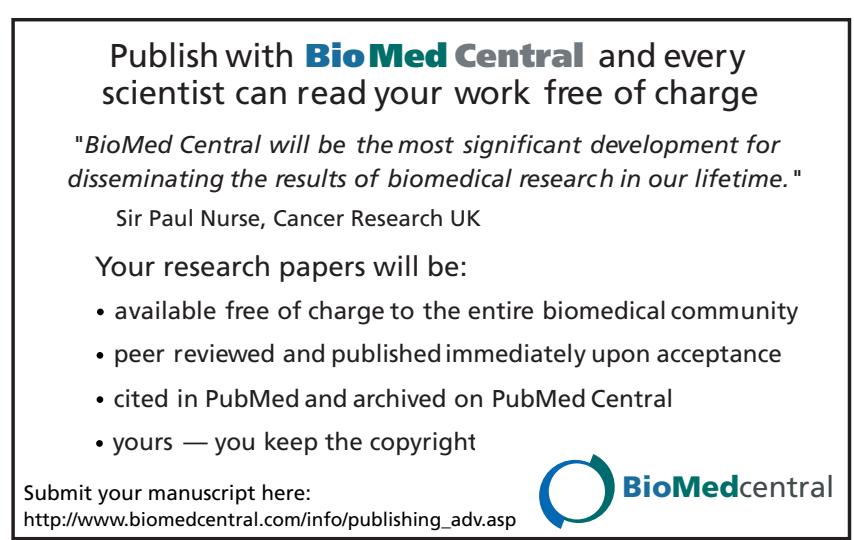

